\title{
TADEU PERNICHELLI
}

Infecção experimental de camundongos C57BL/6 por

$L$. (L.) amazonensis na presença de saliva de $L u$. longipalpis: estudo da relação parasito-hospedeiro com ênfase a parâmetros da imunidade

Dissertação apresentada à

Faculdade de Medicina da

Universidade de São Paulo para obtenção de titulo de Mestre em Ciências

Área de concentração:

Fisiopatologia Experimental

Orientadora:

Prof ${ }^{a}$. Drª . Márcia Dalastra Laurenti

São Paulo

2008 
Se, a principio, a idéia não é absurda, então não há esperança para ela.

Albert Einstein

À minha esposa Andréia, a minha filha Alice e para toda a minha família que acreditou na minha capacidade de chegar até aqui. 


\section{AGRADECIMENTOS}

À minha orientadora, Prof ${ }^{a}$. Drª . Márcia Dalastra Laurenti, agradeço por sua confiança, dedicação e, principalmente, pelo carinho demonstrado em todos os momentos de nossa convivência. Além de orientadora e amiga, seu caráter e profissionalismo serão sempre um exemplo em minha vida.

Agradeço ao Prof. Dr. Carlos Eduardo Pereira Corbett, chefe do Laboratório de Patologia de Moléstias Infecciosas (LIM-50) do departamento de Patologia da Faculdade de Medicina da Universidade de São Paulo, pela compreensão, a confiança e a atenção que dispensou quando cheguei ao laboratório e durante todo o decorrer do projeto.

Não poderia deixar de agradecer todo o apoio dado pela Lia, secretária do Laboratório de Patologia de Moléstias Infecciosas (LIM-50), que me auxiliou não só com seu conhecimento, mas principalmente, com suas palavras de apoio e conforto. Dalila que sempre esteve junta apoiando a realização deste projeto e Bruno que desprendeu os seus conhecimentos para fazer com que eu pudesse passar por mais esta fase da minha vida.

Aos novos e grandes amigos que fiz no Laboratório de Patologia de Moléstias Infecciosas (LIM-50): Thaíse, Edson, Felipe, Michele, Bruna, Carol, Malú, Ana Kelly, Ana Amélia e todos os funcionários e alunos que durante este período sempre deram o seu apoio técnico e principalmente com palavras de 
incentivo nos momentos mais difíceis em que algumas coisas parecem que não funcionam.

Agradeço à Profe. Drª. Claudia Gomes e ao Prof. Dr. Fernando Tobias Silveira o apoio dado e por suas lições de crescimento pessoal e o tempo dedicado para o meu sucesso.

À Profạ . Drạ . Vânia, uma nova amiga do Laboratório de Patologia de Moléstias Infecciosas (LIM-50), agradeço por todo o ensinamento, apoio e carinho dedicados. Presença imprescindível para realização deste projeto e crescimento pessoal.

Agradeço a colaboração do Prof. Dr. Paulo Filemon Paulucci Pimenta e a Drª . Nágila Costa Secundino, e a equipe do Laboratório de Entomologia Médica do Centro de Pesquisas Reneé Rachou - FIOCRUZ, Belo Horizonte (MG), pelas glândulas salivares gentilmente cedidas, indispensáveis para a elaboração e desenvolvimento deste projeto.

Aos professores, que conheci durante as disciplinas cursadas, meus agradecimentos pelo conteúdo técnico-científico ministrado em suas aulas e que contribuiu para o meu desenvolvimento profissional e pessoal.

Aos animais experimentais, meu grande respeito por sua contribuição. 
Agradeço a toda a minha família, minha esposa Andréia, minha filha Alice minha mãe Zeri, meu pai Nelson, as minhas tias Neuza e Arai, aos meus irmãos Cristiano e Suzana por todo o incentivo dado em toda a minha vida. A minha nova família, Fernanda, Carlos e André por todo o carinho e apoio para que eu chegasse até este momento. 
Este trabalho foi desenvolvido no Laboratório de Patologia de Moléstias Infecciosas (LIM-50) do Departamento de Patologia da Faculdade de Medicina da Universidade de São Paulo. Contou com o apoio financeiro da Fundação de Amparo à Pesquisa do Estado de São Paulo - FAPESP, processo número 2001/00240-4. 


Esta tese está de acordo com as seguintes normas, em vigor no
momento desta publicação:
Referências: adaptado de International Commitee of Medical Journals
Editors (Vancouver)
Universidade de São Paulo. Faculdade de Medicina, Serviço de
Biblioteca e Documentação. Guia de apresentação de dissertações,
teses e monografias. Elaborado por Anneliese Carneiro da Cunha,
Maria Julia de A. L. Freddi, Maria F. Crestana, Marinalva de Souza
Aragão, Suely Campos, Valéria Vilhena. $2^{\text {a }}$ ed. São Paulo: Serviço de
Biblioteca e Documentação; 2005.
Abreviaturas dos títulos dos periódicos de acordo com List of Journais
Indexed in Index Medicus




\section{SUMÁRIO}

Resumo

Summary

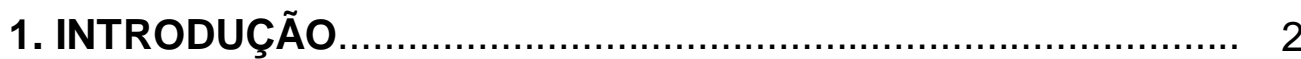

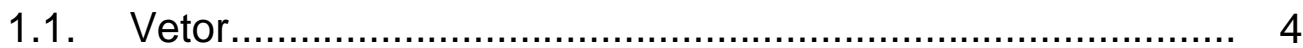

1.2. Leishmania e flebotomíneos............................................. 6

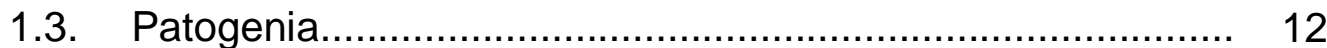

1.4. Interação do parasito com a célula hospedeira: mecanismos de evasão................................................................. 15

1.5. Imunopatologia ........................................................ 19

1.6. Saliva do Vetor......................................................... 22

1.7. A saliva do vetor e a infectividade da Leishmania............... 24

1.8. Saliva e o sistema imune do hospedeiro........................... 26

1.9. A saliva do vetor como um candidato a vacina para leishmaniose............................................................... 27

1.10. Justificativa............................................................... 29

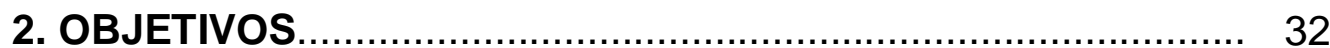

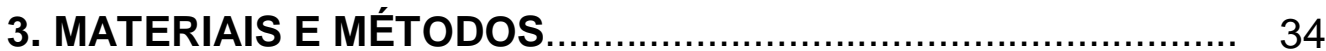

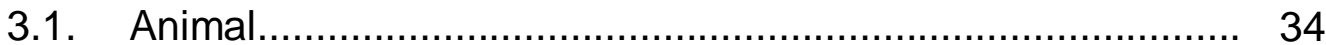

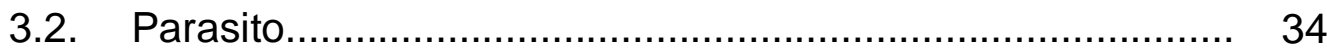

3.3. Glândula Salivar..................................................... 35

3.4. Efeito do Extrato de Glândula Salivar na infecção por L. (L.) amazonensis.......................................................... 36

3.4.1. Protocolo experimental................................................ 36

3.5. Avaliação da evolução do tamanho da lesão da 
orelha.

3.6. Avaliação da evolução do tamanho da lesão da pata.

3.7. Caracterização do fenótipo das células nas lesões cutâneas.

3.8. Preparo do antígeno de L. (L.) amazonensis para estímulo das culturas de células de linfonodo poplíteo

3.9. Cultura de células de linfonodo poplíteo para dosagem de citocinas.

3.10. Determinação das concentrações de citocinas (IL-2, IL-4, IL-10, IL-12 e INF- $\gamma$ ) nos sobrenadantes das culturas de células de linfonodo 42

3.11 Analise Estatística...................................................... 44

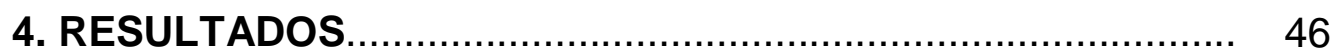

4.1. Evolução do tamanho da lesão................................... 46

4.2. Análise histopatológica da lesão de pele do coxim plantar.

4.3. Análise histopatológica da lesão de pele da orelha

4.4. Caracterização das células recuperadas da lesão da orelha.

4.5. Fenotipagem das células recuperadas da lesão da orelha

4.6. Determinação do perfil de 


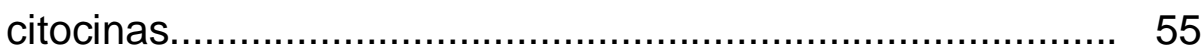

5. DISCUSSÃO

6. CONCLUSÕES

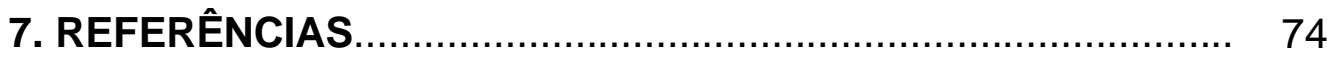




\section{RESUMO}

Pernichelli T. Infecção experimental de camundongos C57BL/6 L.(L.) amazonensis na presença de saliva de Lu. longipalpis: estudo da relação parasito hospedeiro com ênfase a parâmetros da imunidade [Dissertação (mestrado)]. São Paulo: "Faculdade de Medicina, Universidade de São Paulo"; 2008. p89.

Nós investigamos os efeitos da saliva de Lutzomyia longipalpis capturados no campo e colonizados em laboratório, na evolução da lesão e imunomodulação da infecção por Leishmania (Leishmania) amazonensis, uma espécie que é endêmica na América do Sul, onde causa Leishmaniose Cutânea, Leishmaniose Cutânea Disseminada Bordeline e Leishmaniose Cutânea Difusa Anérgica, com conseqüências graves aos pacientes. Com o intuito de comparar o efeito dos dois tipos de extrato de glândula salivar, camundongos C57BL/6 foram inoculados subcutaneamente no coxim plantar das patas traseiras e nas orelhas com $10^{6}$ formas promastigotas de Leishmania (L.) amazonensis na presença de extrato de glândula salivar de vetores de captura e de colônia. O tamanho da lesão foi significantemente menor nos camundongos infectados com extrato de glândula salivar de vetores capturados, o que também determinou uma infiltração menos proeminente de macrófagos nas lesões e uma resposta Th2 mais branda quando comparada com aqueles inoculados com extrato de glândula salivar de vetores colonizados. Recentemente, foi mostradas diferenças nos compostos protéicos das glândulas salivares que poderiam parcialmente 
justificar a expressão da lesão. Portanto, nossos achados ressaltam que a extrato de glândula salivar de flebótomos provavelmente não desempenha um papel importante na exacerbação da infecção por Leishmania já que a transmissão natural do parasito ocorre através de vetores selvagens e não através de vetores colonizados em laboratório.

Descritores: 1.Leishmaniose tegumentar 2.Camundongos 3.Leishmania (Leishmania) amazonensis 4.Psychodidae 5.Saliva/patogenicidade 6.Imunidade celular 7.Citocinas. 


\section{SUMMARY}

Pernichelli T. Experimental infection in C57BL/6 mice by L. (L.) amazonensis in the presence of Lu. longipalpis saliva: Study of parasite host interaction with emphasis to the immunity parameters [Dissertação (mestrado)]. São Paulo: "Faculdade de Medicina, Universidade de São Paulo"; 2008. p89.

We investigated the effects of Lutzomyia longipalpis saliva of vectors captured in the field and colonized in laboratory on the lesion evolution and immunomodulation of the infection by Leishmania (Leishmania) amazonensis, a species that is endemic in South America where it causes cutaneous leishmaniasis, borderline disseminated cutaneous leishmaniasis and anergic diffuse cutaneous leishmaniasis, with devastating consequences to the patients. In order to compare the effect of both salivas, C57BL/6 mice were inoculated subcutaneously into the hind footpads or into the ear dermis with $10^{6}$ promastigotes in the presence of salivary gland homogenate from wildcaught and lab-colonized vectors. Lesion size was significantly lower in the mice infected with saliva from wild-caught sandflies that also determined a less prominent infiltration of macrophages in the lesions and a weaker Th2 response in comparison with those co-inoculated with colonized saliva. Recently, differences were shown in the protein compounds in the salivary glands that could partially account for the lesion size outcome. In conclusion, our findings highlight that phlebotomine saliva probably does not play an important role in the exacerbation of Leishmania infection as the natural 
parasite transmission occurs through wild and not laboratory colonized vectors.

Key Word: 1.Tegmentar Leishmaniasis 2.Mice 3.Leishmania (Leishmania) amazonensis 4.Psychodidae 5.Saliva/Pathogenicity 6.Cellular Immunity 7.Cytokines 
INTRODUÇÃO 


\section{INTRODUÇÃO}

A Leishmaniose Tegumentar Americana (LTA) é uma doença antropozonótica causada por diferentes espécies de protozoários do gênero Leishmania e transmitida através da picada de insetos de diferentes espécies da família Phlebotominae. A infecção se caracteriza pelo parasitismo de células do sistema fagocítico mononuclear e acomete a pele e/ou mucosas de vias aéreas superiores. Esta doença é encontrada em 88 países no mundo e cerca de 400 milhões de pessoas vivem em área de risco, podendo adquirir a doença (Moura et al., 2005).

A Organização Mundial da Saúde (OMS/WHO) estima que a incidência anual da doença pode variar de 1,5 a 2 milhões de casos novos/ano, a maioria decorrente do acometimento tegumentar (WHO, 2004). Levando-se em conta a subnotificação, pode-se estimar que estes números sejam ainda maiores. Em decorrência das diferenças existentes no padrão epidemiológico da leishmaniose tegumentar que ocorre nas Américas, tanto em relação às espécies de Leishmania quanto aos flebotomíneos vetores, as formas clínicas com comprometimento tegumentar têm sido distinguidas em Leishmaniose Tegumentar do Velho Mundo e Leishmaniose Tegumentar Americana (LTA) (Volf et al., 2000; Almeida et al., 2005; Roberts, 2006).

Com relação à história da LTA ela pode ser considerada uma moléstia autóctone do continente americano, sendo conhecida desde antes da chegada dos europeus. Admite-se que as lesões tenham impressionado os artistas da era inca de tal forma que estes esculpiam em suas cerâmicas 
("huacos") deformidades faciais sugestivas do comprometimento mucoso da doença.

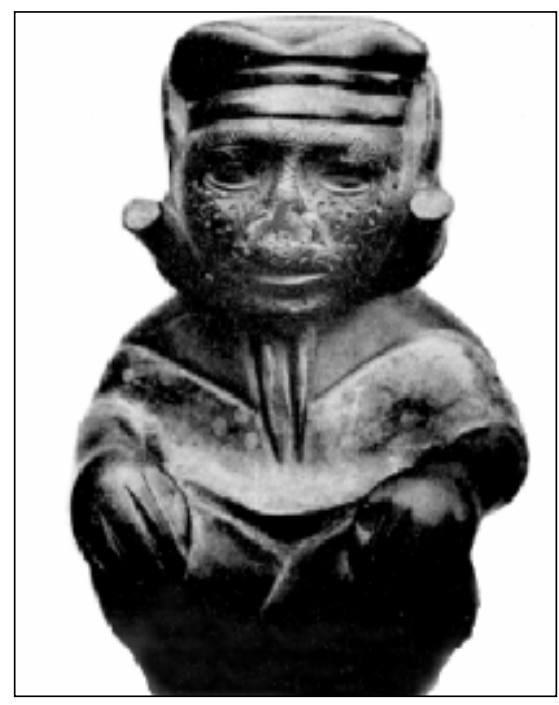

Huaco - Hist.Cienc.Saúde-Manguinhos Set./Dez. 2003

Os parasitos causadores da doença foram descobertos provavelmente por Cunningham (1885) em pacientes com o Botão do Oriente e identificados como Leishmania tropica por Wright (1903). No mesmo ano, Ross criou o gênero Leishmania. Somente em 1909, Lindenberg, assim como Carini e Paranhos, demonstraram, independentemente, a presença de parasitos nas lesões de pacientes brasileiros. Em 1911, Gaspar Vianna descreve o parasito causador da doença em nosso país, diferenciando-o dos protozoários isolados no Velho Mundo e denominando-o Leishmania braziliensis (Pessoa \& Barreto, 1948; Scheriber \& Mathys, 1987). Em 1922, Henrique Aragão associa um surto de leishmaniose no Rio de Janeiro à elevada densidade de flebotomíneos e demonstra a participação destes dípteros na transmissão da doença (Basano \& Camargo, 2004).

Nas Américas, a leishmaniose é endêmica e é considerada uma zoonose primária de mamíferos silvestres como roedores, marsupiais, 
edentados e primatas, entre os quais as diferentes espécies de Leishmania são transmitidas pela picada de insetos flebotomíneos. Ela está presente em 24 países situados desde o Sul dos Estados Unidos até o Norte da Argentina, com exceção apenas do Uruguai e do Chile (Lainson, 1983; Grimaldi et al., 1989).

As principais formas de apresentação da LTA são: Leishmaniose Cutânea Localizada (LCL), Leishmaniose Cutâneo-Mucosa (LCM), Leishmaniose Mucosa (LM), Leishmaniose Cutânea Disseminada Borderline (LCDB) e Leishmaniose Cutânea Anérgica Difusa (LCAD) (Silveira, 2004 e 2005).

Esta doença adquiriu um caráter ocupacional devido ao alto índice de trabalhadores que entram em contato com a mata, onde o ciclo silvestre da doença acontece. Outro aspecto importante para o desenvolvimento no ciclo da doença é a presença de animais domésticos dentro da área de contaminação que, conseqüentemente, participam do aumento de números de casos e da urbanização da enfermidade (Leiby et al., 1994; Solbach \& Laskay, 2000; Cruz et al., 2005; Brasil, Ministério de Saúde, 2007).

\subsection{Vetor}

Os insetos vetores que transmitem a LTA aos hospedeiros intermediário e/ou definitivo são da ordem Díptera, insetos portadores de um par de asas funcionais, da subordem Nematocera por possuírem antenas alongadas e multi-segmentadas, pertencem à família Psychodidae por apresentarem características como asas lanceoladas densamente revestidas de cerdas 
longas com nove ou mais veias e estão classificados na subfamília Phlebotominae e no gênero Lutzomyia por serem transmissores das leishmanioses no Novo Mundo. Possuem nomes populares como cangalha, cangalhinha, mosquito-palha, birigui, tatuíra, entre outros (Cruz et al., 2005; Roberts, 2006; Brasil, Ministério de Saúde, 2007).

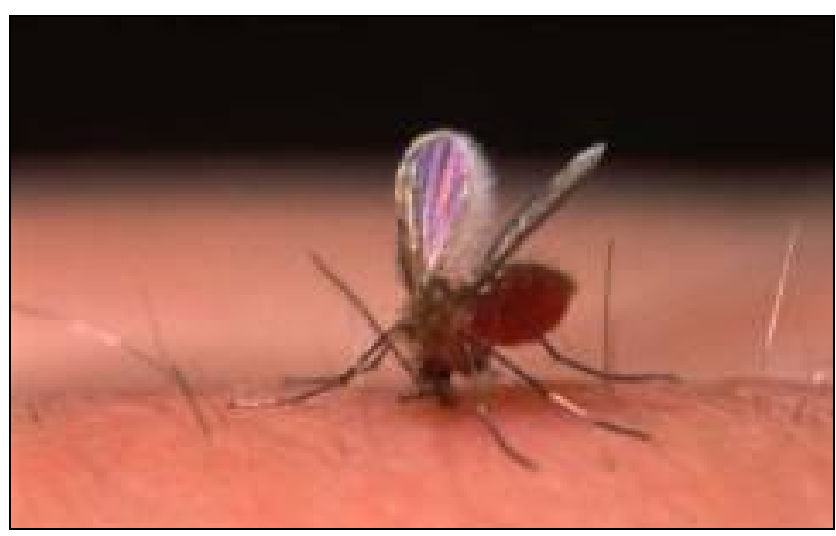

Flebotomíneo.

Algumas características destes insetos são, por exemplo, serem holometábolos, ou seja, em seu ciclo de vida existem as fases de ovo, larva, pupa e o inseto adulto, necessitam de solo com matéria orgânica para que as fêmeas depositem seus ovos a sua locomoção é feita por vôos saltitantes e ao contrário de muitos outros dípteros, suas asas são mantidas eretas quando o inseto está em repouso. Os flebótomos adultos alimentam-se de substâncias açucaradas e somente as fêmeas complementam sua alimentação com sangue de animais silvestres, mamíferos e répteis, pois é uma fonte de proteínas fundamental para a maturação e o desenvolvimento dos ovos.

Durante sua alimentação, os flebotomíneos, por possuírem um aparelho bucal curto, podem chegar até seis vezes a espessura da epiderme que será 
perfurada até que se localize o sangue onde irá se formar sítios hemorrágicos e a conseqüente ingestão do sangue, células e linfa que são oriundos de pequenos capilares. A perfuração da pele só será interrompida quando o inseto reconhecer o gosto do sangue com o auxílio de receptores gustativos localizados nas partes proximais das peças bucais. O reconhecimento é das purinas, que são liberadas com o rompimento das hemácias ingeridas à custa de forte pressão negativas promovidas por bomba de sucção, o cebário e a faringe, que antecedem o esôfago ou outros fagoestimuladores. Este processo só irá terminar quando o estômago estiver completamente ingurgitado, isto fará com que ocorra um estimulo de terminações nervosas no abdome que enviarão sinais ao cérebro para que se interrompa a sucção e as peças bucais sejam retiradas da pele. Semelhante aos outros insetos hematófagos, os flebotomíneos possuem glândulas salivares que auxiliam durante a alimentação tanto do sangue como de açúcar. Duas glândulas salivares saculares, localizadas no tórax, desembocam em ductos salivares que forma um canal por todo o comprimento da hipofaringe. Este arranjo das partes bucais permite a secreção da saliva durante o processo do repasto sanguíneo realizada pelo inseto (Schoeler \& Wikel, 2001; Soares \& Turco, 2003; Cruz et al., 2005; Lainson \& Rangel, 2005; Kamhawi, 2006; Rogers \& Bates, 2007; Warburg, 2008.

\subsection{Leishmania e flebotomíneos}

As diversas espécies de Leishmania que infectam o homem e são agentes de diferentes formas clínicas de leishmanioses descritas no Brasil, 
têm mecanismos de transmissão idênticos e desenvolvem um ciclo muito semelhante ao longo do tubo digestivo dos seus vetores flebotomíneos preferenciais. O ciclo de todas as leishmanias que infectam o homem se inicia de forma idêntica, mas à medida que a infecção se estabelece propriamente, configura-se uma nítida preferência de locais para a colonização ao longo do trato digestivo. Essa diferença de comportamento no inseto vetor passou a ser usada como instrumento taxonômico para a distinção biológica entre subgêneros de Leishmania. O ponto anatômico tomado como referência foi o piloro, ou seja, o local de junção dos intestinos médio e posterior e para onde convergem os túbulos de Malpighi. As espécies cuja colonização se dá predominantemente nas porções anteriores do estômago, principalmente na sua porção torácica, são ditas de comportamento suprapilárico e estão agrupadas no subgênero Leishmania. Por outro lado, as espécies que colonizam tanto a região posterior da porção abdominal do estômago quanto à pilórica, padrão de desenvolvimento denominado peripilórico ou peripilárico, foram agrupadas no subgênero Vianna (Lainson \& Shaw, 1987; Soares \& Turco, 2003; Cruz et al., 2005).

A Leishmania é um parasito digenético (heteroxeno), cujo ciclo vital se passa no hospedeiro vertebrado e no invertebrado, apresentando-se sob duas formas evolutivas: amastigotas e promastigotas. Essas estruturas têm em comum um complexo flagelar composto de vacúolo contrátil, bolsa flagelar e flagelo. As amastigotas são estruturas arredondadas, com flagelo rudimentar não exteriorizado, que se localizam em vacúolos parasitóforos de células fagocitárias de vertebrados, sobretudo macrófagos. A forma promastigota é alongada, provida de flagelo livre e se desenvolve no tubo 
digestivo do inseto vetor. Ambas possuem um cinetoplasto que consiste em uma mitocôndria modificada, contendo grande quantidade de DNA (Leiby et al., 1994; Sacks \& Kamhawi, 2001; Vannier-Santos et al., 2002; Cruz et al., 2005).

A manutenção da infecção por Leishmania nos hospedeiros vertebrados se dá através da multiplicação das formas amastigotas dentro de células do sistema fagocítico mononuclear. Embora formas amastigotas possam circular no sangue dentro de células que fazem parte desse sistema, é na pele sã ou com lesão que está a maior parte das células infectadas. Os vetores das leishmanioses no Brasil, flebotomíneos do gênero Lutzomyia, são insetos que possuem peças bucais relativamente curtas, que não permitem uma penetração profunda e punção diretamente dos vasos. Em conseqüência, estes vetores rasgam a pele da vítima e dilaceram os tecidos provocando uma hemorragia, da qual drenam o sangue, célula e linfa dos minúsculos capilares rompidos por suas peças bucais. Devido a esse modo de se alimentar diretamente no tecido cutâneo, flebotomíneos podem ingerir formas amastigotas de Leishmania aí presentes, juntamente com o sangue oriundo dos pequenos vasos cortados por suas peças bucais (Alexander et al., 1999; Almeida et al., 2003; Cruz et al., 2005; Leiby, 1994; Soares \& Turco, 2003).

As formas amastigotas, ingeridas durante o repasto, logo se diferenciam em formas promastigotas ainda no meio da massa de sangue por digerir. Tal transformação permitirá que os parasitos sobrevivam à digestão que logo se iniciará. As formas promastigotas possuem resistência às enzimas digestivas, conferida por uma cobertura glicolípidica (lipofosfoglicana) que envolve todo o corpo do parasito, inclusive o seu flagelo, mas que é inexistente nas 
amastigotas tomadas do vertebrado. Enquanto o estômago do inseto secreta a matriz peritrófica, que estará completamente formada em cerca de 24 horas, as formas promastigotas se dividem intensamente livres no bolo alimentar envolto pela matriz peritrófica (Sacks \& Kamhawi, 2001; VannierSantos et al., 2002). Enzimas proteolíticas secretadas pelo epitélio do estômago atravessarão a matriz peritrófica e iniciarão a digestão do sangue, destruindo as formas amastigotas retardatárias e que ainda não se diferenciaram em promastigotas. Estas formas já diferenciadas de uma espécie de Leishmania são igualmente destruídas se ingeridas por uma espécie de flebotomíneo de baixa competência vetorial, o que sugere especificidade de condições bioquímicas neste primeiro momento de desenvolvimento do parasito no inseto. As formas promastigotas fixadas no estômago de um vetor competente resistirão e se multiplicarão por divisão binária mesmo durante os repastos seguintes. Com o final da digestão, a matriz peritrófica começa a se desintegrar e os resíduos alimentares nela contidos passarão ao intestino posterior. Porém, as formas promastigotas em multiplicação precisarão escapar para o espaço exterior à matriz peritrófica a custa de secreção de quitinases para, em seguida, multiplicar-se e fixar-se no epitélio intestinal. A adesão das formas promastigotas é feita à custa de fosfoglicanas que se ligam às microvilosidades das células epiteliais. Esta adesão é essencial para que a infecção se estabeleça definitivamente, caso contrário os parasitos podem ser excretados a qualquer momento, como acontece em espécies não competentes para a transmissão de determinada Leishmania. Após a adesão, segue-se a metaciclogênese, ou seja, a diferenciação em promastigotas metacíclicos capazes de infectar o 
hospedeiro vertebrado. Tais formas podem começar a aparecer quatro dias após o repasto, mas é com cerca de uma semana que os parasitos se movem em direção à porção anterior do trato digestivo e passam para o intestino anterior (Volf et al., 2000; Ilg, 2000; Späth et al., 2000; Cunningham, 2002; Späth et al., 2003; Cruz et al., 2005).

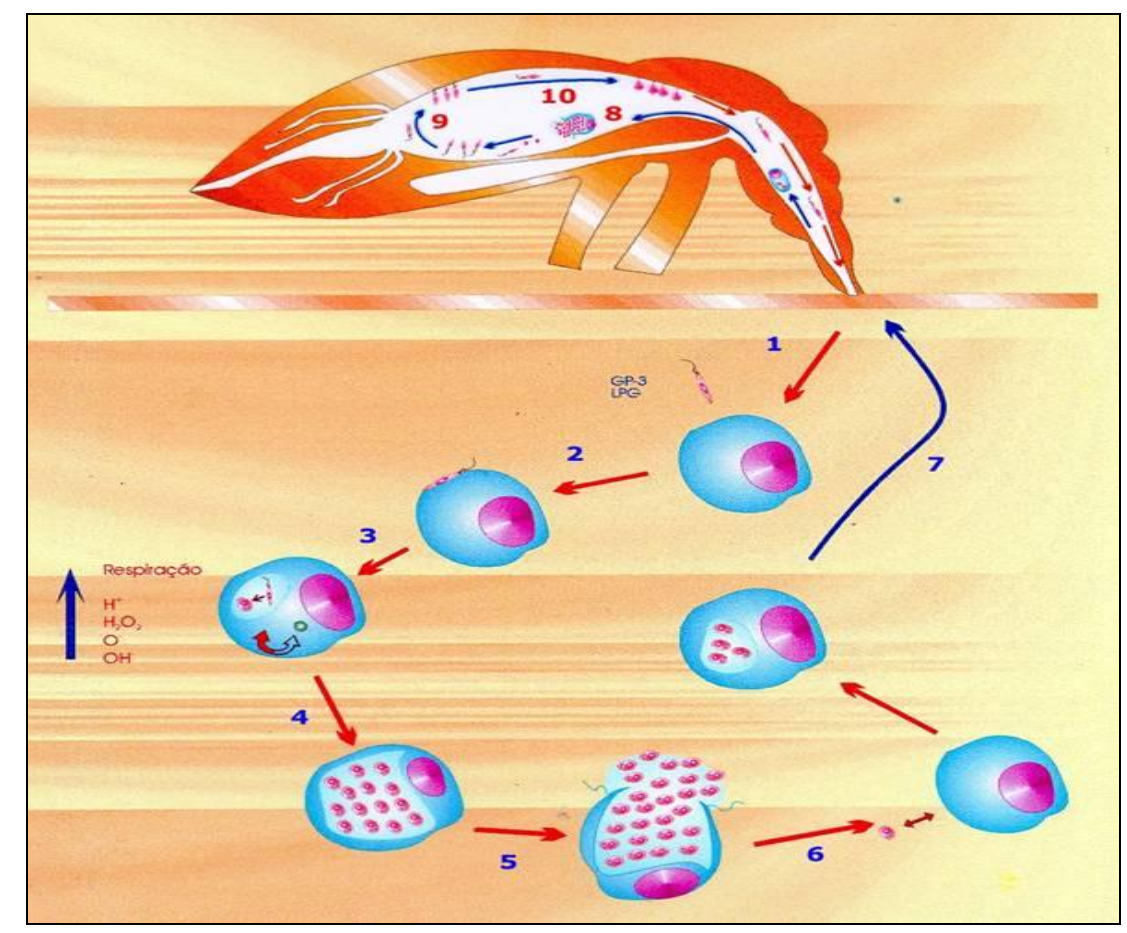

Ciclo de vida - Leishmania sp.

Em todas as combinações de espécies de Leishmania/vetor até agora estudadas, verificou-se haver um simultâneo acúmulo de promastigotas metacíclicas e bloqueio da porção anterior do intestino médio por um tampão gelatinoso secretado pelos próprios parasitos nele contidos. O componente principal deste gel secretado pelas promastigotas é uma proteofosfoglicana filamentosa (fPPG), uma glicoproteína incomum semelhante à mucina unicamente produzida por Leishmania. Foi demonstrado que a quantidade de fPPG no trato digestivo do flebotomíneo infectado com Leishmania aumenta 
conforme avança a infecção, alcançando o seu pico no sétimo dia. Isso coincide com o auge da formação, migração e acúmulo de formas infectantes, os promastigotas metacíclicos, na faringe, na cárdia e no esôfago. O tampão gelatinoso de origem parasitária bloqueia essas porções do tubo digestivo do inseto infectado, o qual passa a ter dificuldade em sugar sangue. Com isso, durante o repasto sanguíneo, um flebotomíneo nesse estágio de infecção tentará se livrar desse bloqueio regurgitando os parasitos juntamente com o gel diretamente dentro do tecido cutâneo do hospedeiro vertebrado lacerado durante a picada. Essa dificuldade em sugar sangue faz com que o inseto cometa múltiplas e demoradas tentativas de alimentação em um mesmo hospedeiro ou em hospedeiros variados. Por conseguinte, aumentam as chances de transmissão do patógeno (Rogers, 2004; Cruz et al., 2005).

A composição do material regurgitado pelo inseto infectado juntamente com as promastigotas metacíclicas não só facilita como também favorece a exacerbação da infecção e lesão causada pela inoculação de Leishmania no hospedeiro vertebrado. O gel secretado pelo parasito tem várias vantagens para uma efetiva transmissão da Leishmania, seja pelo bloqueio do tubo digestivo do vetor, seja pela capacidade em aumentar a sobrevivência dos parasitos regurgitados na pele do hospedeiro. Por outro lado, a inoculação do gel secretado pelo vetor, cujo componente ativo principal é fPPG, pode levar também a um quadro de proteção para alguns indivíduos expostos constantemente a picadas do inseto. Isto foi comprovado em modelos experimentais, nos quais foi observada a cura das lesões (Rittig \& Bogdan, 2000; Cunningham, 2002). 


\subsection{Patogenia}

A resposta imune desenvolvida na LTA demonstra que pacientes infectados com Leishmania têm a capacidade de montar uma reação de hipersensibilidade tardia e de induzir a expansão de linfócitos T circulantes antígeno-específicos (Solbach \& Laskay, 2000; Silveira et al., 2004; Cruz et al., 2005). A resposta imune celular parece desempenhar um papel fundamental no curso evolutivo da infecção. O desenvolvimento da resposta imune é precoce, podendo preceder até mesmo o aparecimento da lesão tegumentar ou mesmo controlar a infecção, evitando o surgimento das lesões cutâneas em alguns casos (Silveira et al., 2005). Indivíduos que vivem em áreas endêmicas mostram-se mais resistentes ao desenvolvimento da doença quando comparados a indivíduos que se deslocam para estas áreas. Isso ocorre provavelmente devido a um processo gradual de adaptação do sistema imune, conferindo imunidade contra o parasito pela exposição prévia a picado do vetor e, conseqüentemente exposição à saliva (Barral et al., 2000; Cruz et al., 2005; Andrade et al., 2007)

Estas características podem direcionar, também, para perfis diferentes relacionados com as manifestações clínicas, histopatológicas e imunopatológicas da doença. Desta forma, a infecção poderia manter-se de forma assintomática em indivíduos com a imunidade capaz de conter a infecção ou resultar num leque espectral de manifestações clínicas na pele e/ou mucosa nasobucofaríngea, traduzidas por lesões cutâneas isoladas (Leishmaniose Cutânea Localizada), lesões cutâneas disseminadas 
(Leishmaniose Cutânea Disseminada), lesões cutâneo-mucosas (Leishmaniose Cutâneo-mucosa), lesões mucosas isoladas (Leishmaniose Mucosa) e lesões cutâneas difusas (Leishmaniose Cutânea Anérgica Difusa) (Silveira et al., 2004). A evolução para a cura está associada à indução de citocinas produzidas pelas células TCD4+ do tipo Th1 e ausência de IL-4. A expressão de RNA mensageiro nas lesões e o padrão de citocinas produzidas por células $\mathrm{T}$ reativas a Leishmania, claramente evidenciam um perfil misto de resposta imune celular Th1 (IFN- $\gamma$ ) e Th2 (IL-4, IL-5) durante a fase ativa das lesões, com predomínio de Th1 nas lesões cutâneas (Leiby et al., 1994; Solbach \& Laskay, 2000). Tem sido sugerido que a diminuição de citocinas de Th2 e o aumento de células $\mathrm{TCD}^{+}$poderiam contribuir para a resolução da lesão, através do aumento da atividade citotóxica específica sobre macrófagos parasitados ou de mecanismos relacionados à maior ativação de macrófagos pelo INF- $\gamma$ (Carvalho et al., 2007).

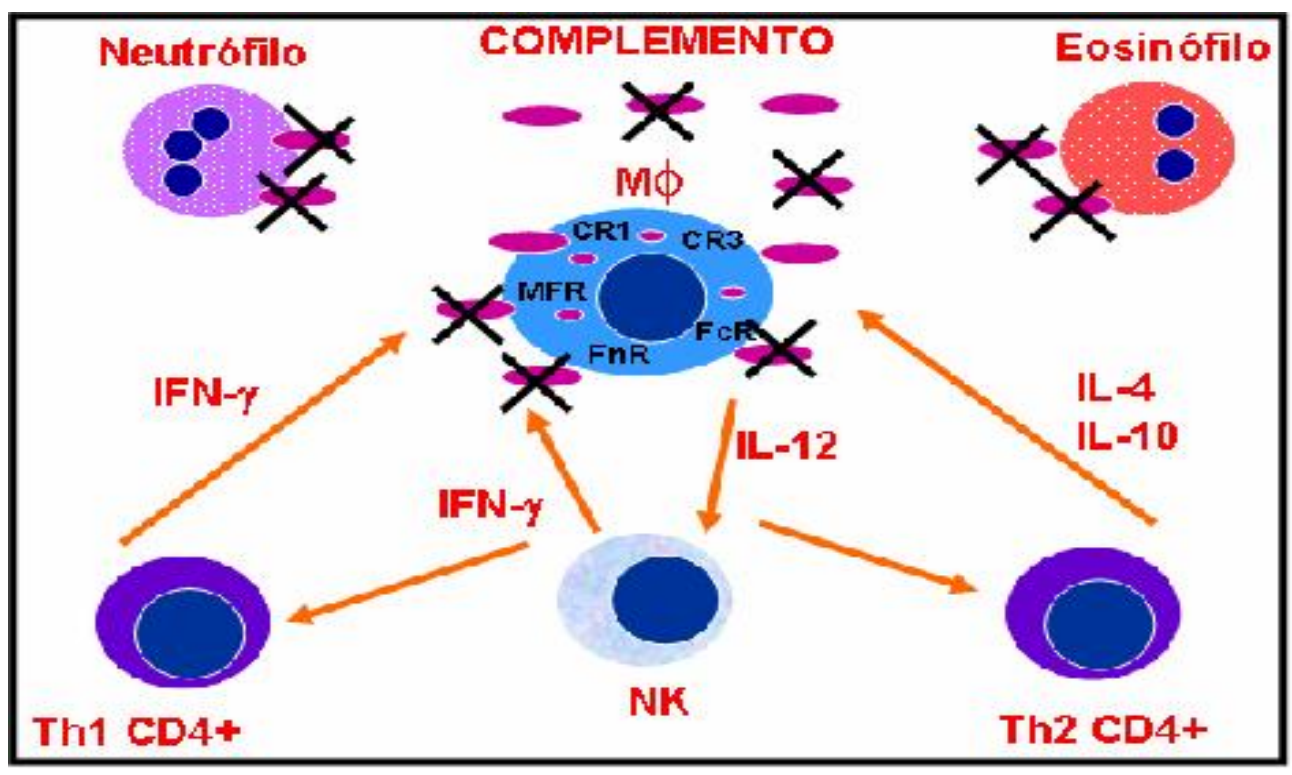

Resposta Inflamatória para infecção por Leishmania sp. 
Em modelos experimentais (BALB/c, C57BL/6) tem sido demonstrado que diferentes espécies de Leishmania podem causar manifestações clínicas distintas, que podem ser desde lesões superficiais até uma possível visceralização da doença. Isto se deve a suscetibilidade do hospedeiro à carga parasitária inoculada (Lipoldová et al., 2002).

Aspectos da imunologia da infecção por Leishmania têm sido estudados, principalmente, utilizando-se L.major em camundongos das linhagens C57BL/6, C3H, CBA que conseguem ter controle da infecção primária, tidos como modelo de resistência; e em camundongos BALB/c que não demonstra controle eficaz, portanto desenvolvendo uma doença sistêmica letal (Alexander et al., 1999; Lipoldová, 2000; Almeida et al., 2003; Awasthi et al., 2004; Cruz et al., 2005). O modelo experimental utilizando a infecção de L.major em camundongos mostrou, modelos clássicos de resposta imune celular do tipo Th1 e Th2 com relação à infecção intracelular, entretanto é de suma importância avaliar outros modelos para que se tenham perfis da doença causada por outras espécies de Leishmania (Leiby et al., 1994; Solbach \& Laskay, 2000).

Tanto no modelo experimental, como na infecção humana as subpopulações de linfócitos T circulantes e o painel de citocinas (IFN- $\gamma$, IL-2, IL4, IL-5, IL-10, IL12, TNF- $\alpha$, TNF- $\beta$ ) produzidos por estas células estão associados aos processos de desenvolvimento da doença, assim como da evolução para a cura e a proteção (Awasthi et al., 2004; Oliver et al., 2005; Murray et al., 2006).

Após a picada do inseto, na infecção natural, ou a inoculação do parasito experimentalmente ocorre uma evolução da infecção com o 
desenvolvimento de lesões cutâneas, e quando ocorre uma modulação adequada da resposta imune a lesão tende a desaparecer. Os estudos de caracterização dos linfócitos $\mathrm{T}$ circulantes reativos para Leishmania realizados em pacientes de leishmaniose cutânea mostram que na doença ativa há uma indução preferencial de células $\mathrm{TCD}^{+}$, enquanto um aumento da proporção de células $\mathrm{TCD}^{+}$é verificado durante o processo de cura (Soares \& Turco, 2003; Campanelli et al., 2006; Carvalho et al., 2007).

\subsection{Interação do parasito com a célula hospedeira: mecanismos de evasão.}

O primeiro contato do parasito com a célula hospedeira é caracterizado por uma interação ligante-receptor entre as moléculas de superfície de ambos, seguida por uma série de reações bioquímicas que pode levar à ativação ou à inibição das funções da célula hospedeira (Sacks \& Kamhawi, 2001; Almeida et al., 2003).

A Leishmania se liga a diferentes receptores encontrados na superfície dos macrófagos, como ao receptor da fração Fc da imunoglobulina, aos receptores do complemento $\mathrm{CR} 1$ e $\mathrm{CR} 3$, ao receptor de fibronectina e a um receptor para produtos de glicosilação não enzimática (Silveira, 2003).

Por outro lado, dentre as diferentes moléculas integrantes da membrana de superfície dos parasitos encontram-se glicoconjugados tais como glicoproteínas e glicolipídeos que são importantes na sua interação com o macrófago, podendo determinar a sobrevivência do parasito. Estes carboidratos de superfície são importantes na adesão do parasito ao 
macrófago, e às células do trato digestivo do inseto vetor (Sacks \& Kamhawi, 2001; Tuon et al., 2008).

Das várias moléculas de superfície envolvidas nesta interação, uma glicoproteína de peso molecular de 63kD (gp63) e o lipofosfoglicano (LPG) são as principais moléculas da superfície da Leishmania que se ligam ao macrófago. Esta ligação ocorre principalmente com receptor $\mathrm{CR} 3$, para a fração C3bi do complemento, mesmo na ausência de opsoninas do soro. Além da ligação ao CR3, a gp63 pode se ligar à célula hospedeira através do receptor para manose e fucose. Vários estudos também indicam a importância da interação direta entre sacarídeos de LPG e gp63 e o receptor lectina-símile do macrófago (Leiby et al., 1994; Solbach \& Laskay, 2000; Mosser et al., 1986).

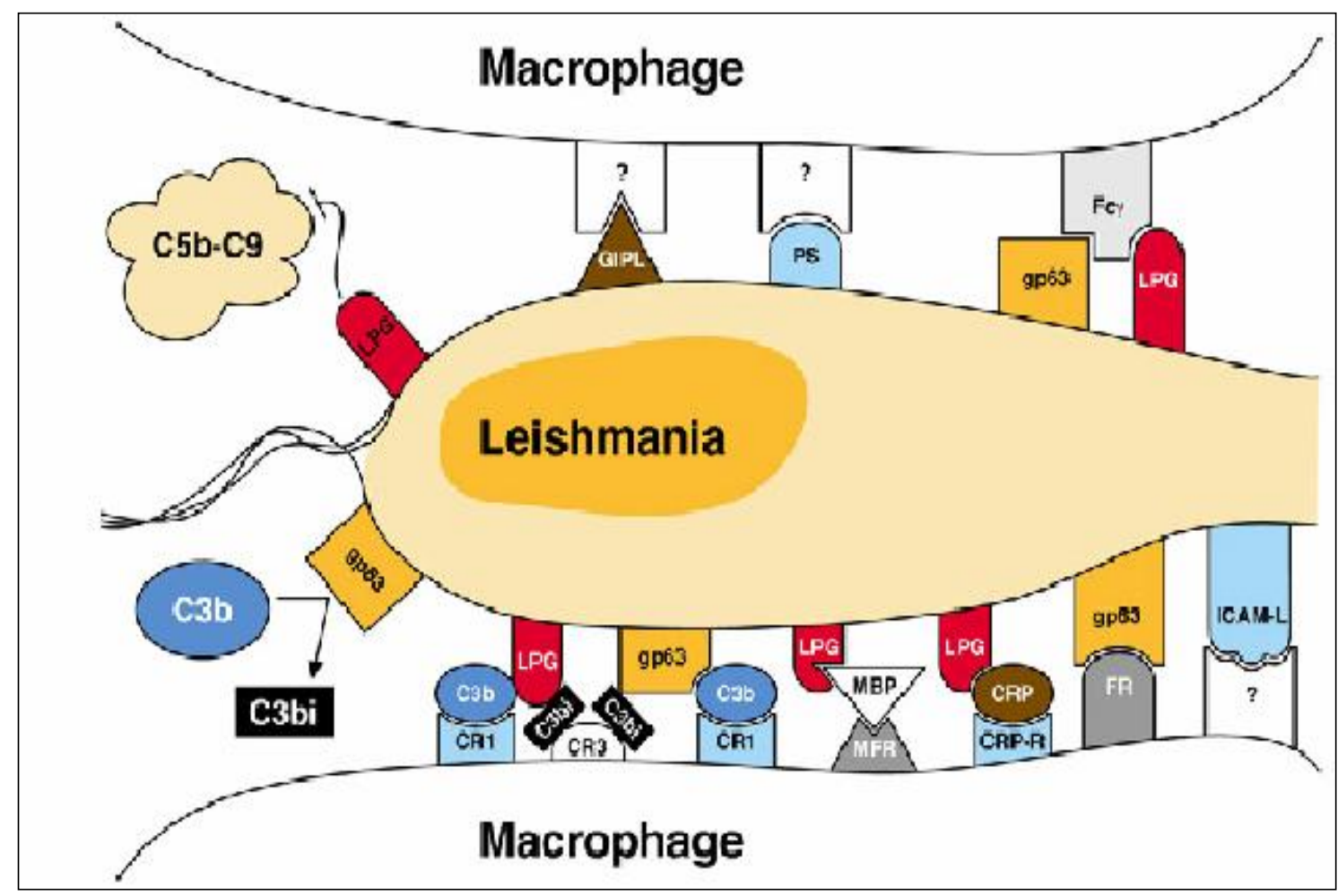

Interação entre macrófago e Leishmania sp via receptores de membrana e proteínas solúveis; Geneviève Forget. 
Porém a sobrevivência do parasito na célula hospedeira depende da sua capacidade de evasão dos mecanismos de defesa do hospedeiro vertebrado.

Uma das principais defesas do homem à infecção pela Leishmania refere-se aos mecanismos microbicidas do macrófago, cuja principal função é destruir o parasito. A ligação das formas promastigotas metacíclicas à superfície da célula hospedeira desencadeia um fenômeno oxidativo celular, gerando metabólitos tóxicos de oxigênio, superóxido $\left(\mathrm{O}_{2}{ }^{-}\right)$, radical hidroxila $\left(\mathrm{OH}^{-}\right)$e, especialmente, peróxido de hidrogênio $\left(\mathrm{H}_{2} \mathrm{O}_{2}\right)$ que tem sido responsabilizado pela principal atividade leishmanicida do macrófago. Além da resposta oxidativa, o macrófago possui outros mecanismos microbicidas, como é o caso do óxido nítrico (NO), gerado a partir da reação do aminoácido L-arginina com o oxigênio molecular (Awasthi et al., 2004; Mukbel et al., 2007).

A inibição da produção de radicais oxidativos do macrófago é considerada um dos principais mecanismos de evasão do parasito. Após a infecção, há ativação do sistema complemento que gera fragmentos C3b e C3bi que, por sua vez, depositam-se na membrana do parasito e passam então a atuar como ligantes dos receptores CR1 e CR3, respectivamente. Quando o parasito utiliza principalmente estes receptores da membrana do macrófago para a sua adesão e internalização, um baixo metabolismo oxidativo da célula hospedeira é desencadeado, constituindo assim um mecanismo essencial para a sobrevivência intracelular da forma promastigota infectiva (Mosser, 2003; Murray et al., 2005). 
A presença de moléculas de fosfatase ácida na membrana dos parasitos também contribui para a redução da resposta oxidativa (Vannier-Santos et al., 2002).

A transformação em formas amastigotas no hospedeiro vertebrado é também referida como mecanismo de evasão importante, uma vez que a fagocitose de amastigotas desencadeia menor metabolismo oxidativo no macrófago quando comparadas às formas promastigotas. As formas amastigotas do parasito são mais resistentes à presença de peróxido de hidrogênio devido à produção da enzima catalase. Além disso, elas produzem superóxido dismutase que as protege de metabólitos do oxigênio produzidos pelos macrófagos durante o processo de fagocitose (Sacks \& Kamhawi, 2001; Almeida et al., 2003; Cruz et al., 2005).

A adesão da Leishmania à membrana do macrófago é um pré-requisito para a fagocitose. Neste processo, são emitidas extensões filamentosas pela superfície da célula hospedeira que englobam o parasito. Após a internalização do parasito, o vacúolo parasitóforo sofre fusão com lisossomas secundários. Esta fusão resulta em maior acidez ( $\mathrm{pH}$ entre 4,7 e 5,2) do fagolisossoma. Este microambiente hostil ao parasito faz com que este se utilize de uma variedade de estratégias para assegurar a sua sobrevivência, dentre elas, a sua capacidade de transformação de forma promastigota (flagelado aeróbio) em forma amastigota (anaeróbio). Já que estudos do metabolismo das amastigotas e de culturas axênicas em meio ácido indicam que estas formas são acidofílicas e resistentes as hidrolases lisossomais e, deste modo, totalmente adaptadas as condições de pH encontradas nos prélisossomos. Além disto, a ação de uma bomba de prótons com atividade 
ATPase, situada no lado citoplasmático da membrana das formas amastigotas, é responsável pela manutenção do pH no seu citoplasma em torno de 6,2 (Vannier-Santos et al., 2002).

Convém ressaltar que a gp63, encontrada em abundância na superfície de formas amastigotas, aumenta a sobrevivência do parasito por degradar enzimas lisossômicas e exibir atividade ótima sob as condições acidofílicas do fagolisossomo (Joshi et al., 2002).

\subsection{Imunopatologia}

Vários componentes da resposta imune inata como fatores do complemento, neutrófilos, citocinas e quimiocinas participam do mecanismo de defesa contra a Leishmania. No entanto, a resposta adaptativa Th1 com a produção de citocinas como INF- $\gamma$ e TNF- $\alpha$, é o principal mecanismo de defesa contra este parasito (Belkaid et al., 2000; Pinheiro \& Rossi-Bergmann, 2007).

A Leishmania é transmitida ao homem pela picada do flebótomo, onde se multiplicam na forma promastigota. Após a inoculação na pele destas formas, é desencadeado mecanismo de defesa anterior a resposta imune adquirida, representados pela resposta inflamatória aguda inespecífica, da qual participam fatores séricos e celulares. Dentre os elementos celulares, encontram-se os fagócitos (neutrófilos, monócitos), eosinófilos, mastócitos, basófilos e células NK; já os fatores séricos, são proteínas com ações inflamatórias, bloqueadoras e anti-inflamatórias como as do sistema 
complemento, etc (Bittencourt \& Barral, 1991; Laurenti et al.; 1996; Ji et al., 2003).

Participam do sistema complemento um conjunto de cerca de 20 proteínas dispersas no plasma, as quais, quando ativadas, podem mediar reações inflamatórias e formar um complexo de ataque à membrana capaz de causar danos diretos ao parasito através da destruição de suas membranas. A susceptibilidade da Leishmania ao sistema complemento depende, fundamentalmente, do estágio de desenvolvimento do parasito. Estudos demonstram que promastigotas de L. (L.) donovani em fase logarítmica de crescimento são mortas a sua totalidade pela ação do soro humano normal na presença de complemento, enquanto 10 a $20 \%$ sobrevivem à ação deste soro quando se encontram em fase estacionária (Chakraborty et al., 2001). Esta diferença na susceptibilidade é independente da quantidade de C3 depositada na superfície do parasito, mas está relacionada com a diferença de tamanho da molécula de LPG do parasito onde será depositado o complexo C5b-9. Além disso, uma proteína quinase (LPK-1), disposta externamente nas formas promastigotas da Leishmania em fase estacionária de crescimento, fosforila o componente C3 do complemento, interferindo na ativação de componentes terminais deste sistema atuando como um fator protetor da lise do parasito (Bogdan, 2008).

Um papel concomitante do sistema complemento é a possibilidade de fixação de fragmentos (C3b e C3bi) na superfície das formas promastigotas metacíclicas e posterior interação com os receptores de superfície dos macrófagos (CR1 e CR3). Neste processo ocorre fraca ativação da resposta 
oxidativa do macrófago facilitando a internalização dos parasitos na célula alvo (Vannier-Santos et al., 2002).

Na leishmaniose cutânea, os macrófagos da derme são as células hospedeiras mais parasitadas sendo também as células efetoras mais importantes pela sua atividade leishmanicida com a produção de radicais livres em resposta ao INF- $\gamma$. Por sua vez, as células epidérmicas de Langerhans são normalmente infectadas com uma carga parasitária baixa, uma ou duas amastigotas por célula, e restrigem a replicação parasitária de maneira independente do óxido nítrico, mas são críticas na indução da resposta imune específica por serem responsáveis pelo transporte de parasitos aos linfonodos regionais, local onde esta resposta se inicia (PonteSucre et al., 2001; Moll et al., 2002). O equilíbrio da infecção depende de alguns fatores: após a penetração, as leishmanias induzem a produção de TNF- $\alpha$ pelos macrófagos, o que potencializa a ação do INF- $\gamma$ que vai promover a ativação dos macrófagos; por outro lado induz também a produção de TGF- $\beta$ que inibe o INF- $\gamma$, estando, portanto, relacionada ao bloqueio da ativação dos macrófagos (Lang et al., 2003; Rohousová et al., 2005; Mora et al., 2005; Leopoldo et al., 2005). Dentro da dinâmica do processo inflamatório, em sua fase inicial, observa-se a importância de leucócitos polimorfonucleares (PMN), como neutrófilos e eosinófilos, no papel de células fagocitárias dos parasitos que, com o auxilio de imunoglobulinas e do sistema complemento, matam os parasitos por ativação do sistema microbicida dependente de oxigênio.

Um dos principais mecanismos de defesa contra parasitos do gênero Leishmania é a ativação dos macrófagos pelo INF- $\gamma$, citocina esta produzida 
por células Th1, as quais são diferenciadas a partir de células Th0 pela ação principalmente do IL-12. Porém, a Leishmania é capaz de escapar da lise intracelular por inibir a produção de IL-12 pelas células apresentadoras de antígenos. Além disto, estes parasitos inibem a expressão de MHC classe II nos macrófagos, endocitam e degradam estas moléculas bem como a $\beta-2$ microglobulina, reduzindo a capacidade apresentadora de antígenos aos linfócitos T CD4+. Diminuição da expressão da molécula co-estimulatória B71 é observada em macrófagos infectados por Leishmania o que também compromete a ativação eficiente da resposta imune celular (Kane \& Mosser, 2001; Vannier-Santos et al., 2002; Cruz et al., 2005; Hölscher et al., 2006).

\subsection{Saliva do Vetor}

As glândulas salivares dos flebotomíneos possuem um complexo de moléculas biologicamente ativas, sendo que as mais estudadas são a apirase e o maxadilan (Moris et al., 2001; Thiakaki et al., 2005).

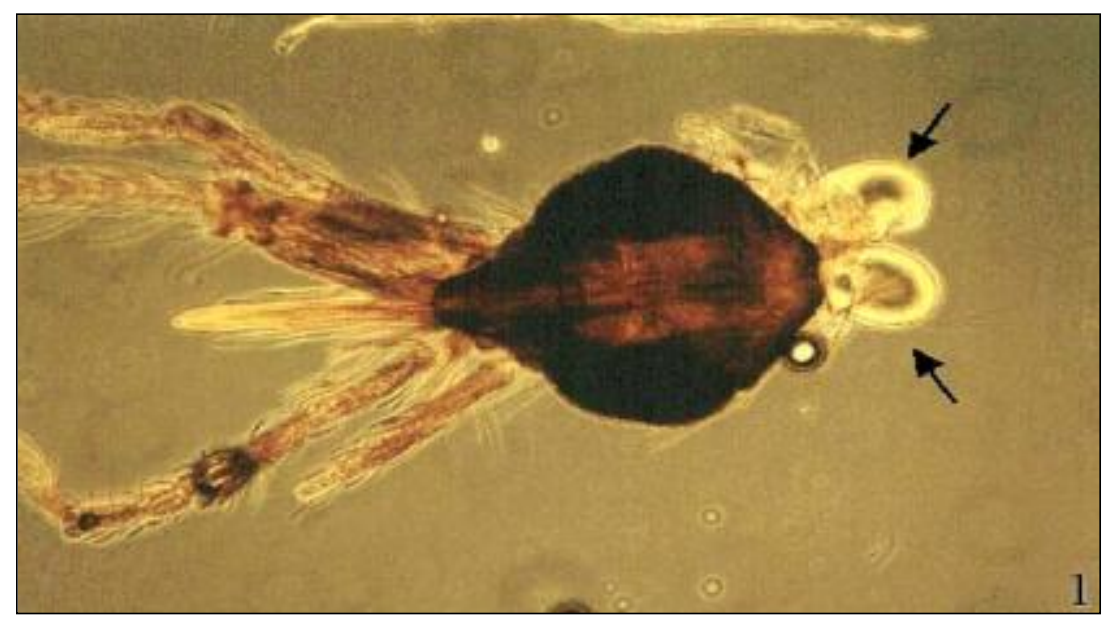

Glândula salivar $(\rightarrow)$ de Flebotomíneos. 
A apirase é uma enzima com função anti-agregação plaquetária capaz de hidrolisar o ATP e o ADP transformando em AMP e fosfato inorgânico. Esta enzima é encontrada tanto no gênero Phlebotomus como no gênero Lutzomyia, vetores do Velho e Novo Mundo, respectivamente. A presença dessa enzima em quase todos os insetos hematófagos demonstra o quanto é importante 0 ADP no processo de agregação plaquetária e conseqüentemente, na hemostasia do hospedeiro (Volf et al., 2000; Wahba \& Riera, 2006)

Ao contrário da apirase, o maxadilan só é encontrado no vetor do Novo Mundo, Lutzomyia longipalpis. Ele é um potente vasodilatador, sensível a tripisa, com as propriedades de formação de eritema (EIF) e possui características funcionais semelhantes ao gene relacionado ao peptídeo calcitonina (CGRP) (Solbach \& Laskay, 2000; Sousa et al., 2001). Foi demonstrada a capacidade do maxadilan de relaxar anéis aórticos, em potência maior que o CGRP (Cruz et al., 2005). A clonagem do maxadilan mostrou que ele possui receptores para tecidos vasculares e neurais e que tem uma ação agonista para o receptor tipo 1 do PACAP (neuropeptídeo com função dilatadora). A remoção da região central do maxadilan elimina sua função de induzir o cAMP e formação de eritema mesmo não perdendo a capacidade de receptor do PACAP. Foi demonstrado ainda que o maxadilan tem capacidade de atuar no endotélio, tanto na parede como em músculo liso com acúmulo de cAMP. Os efeitos do maxadilan são encontrados mesmo em grupos de Lu. longipalpis com variabilidade genética (Valenzuela, 2002; Cruz et al., 2005; Teixeira et al., 2005; Monteiro et al., 2007). 
Nos flebotomíneos do Velho Mundo encontrou-se adenosina e um precursor de 5'AMP com propriedades vasodilatadoras e anti-agregação plaquetária e capacidade de atividade mesmo em baixas concentrações (aproximadamente $1 \mathrm{nmol})$.

Algumas outras enzimas da glândula salivar de Lu. longipalpis, naturalmente secretadas, foram identificadas por clonagem (Kamhawi, 2000), entre elas:

- 5'-nucleotidase: com atividade fosfoesterase

- Hialuronidase: auxilia a ação do maxadilan e sugere-se que tem ação contra outros microorganismos agindo na despolimerização do ácido hialurônico

- proteína anti-coagulação

- $\alpha$-amilase

- Lulo RGD que tem ação anti-plaquetária.

$\mathrm{Na}$ saliva de Lu. longipalpis também se encontrou adenosina, que possui funções como: retardar efeitos apoptóticos em células $T$, efeitos de vasodilatação e agregação plaquetária (Wanderley et al., 2006; Bruchhaus et al., 2007). Finalmente, o que se observa é que a saliva do vetor possui um complexo enzimático muito eficiente para escapar das propriedades hemostáticas do hospedeiro.

\subsection{A saliva do vetor e a infectividade da Leishmania}


Nos anos 80 foi quando demonstrou experimentalmente os efeitos da saliva na infecção por Leishmania, em modelo experimental de L. major (10100 parasitos em fase estacionária de crescimento em cultivo) inoculada em coxim plantar de camundongos CBA junto com saliva de Lu. longipalpis. O resultado foi um aumento da lesão e do número de parasitos quando comparados com o controle sem saliva (Titus \& Ribeiro, 1988).

A exacerbação da lesão, utilizando um modelo semelhante ao anterior foi visto também em camundongos resistentes, C57BL/6 e CBA, a infecção por L. major (Mbow et al., 1998; Monteiro et al.; 2007).

A saliva apresenta importância epidemiológica, pois contribui para o aumento da infectividade e do surgimento de novos casos de leishmaniose. Em experimento utilizando-se $L$. braziliensis, agente causador de leishmaniose mucocutânea no Novo Mundo, camundongos BALB/c, foram inoculados na pata traseira e somente aqueles inoculados com o parasito conjuntamente com saliva de Lu. longipalpis desenvolveram lesão (Kamhawi, 2000).

Um ponto ainda a ser esclarecido refere-se à carga parasitária naturalmente inoculada (entre 10-1000 formas promastigotas) e a carga que introduzida experimentalmente $\left(10^{5}-10^{7}\right)$. Em uma lesão de orelha de camundongo, 26 horas após a picada, recuperaram-se aproximadamente 256 parasitos. Isso mostra que a carga parasitária naturalmente inoculada é bem menor do que o utilizado experimentalmente (Theodos et al., 1991).

Estudos mostram que a evolução da infecção por Leishmania na presença de saliva é bem mais severa quando comparada com os controles 
sem saliva, e isto ocorre pela modulação da saliva no sistema imune do hospedeiro (Theodos et al., 1991; Leiby et al., 1994;, Rohousová et al., 2005).

\subsection{Saliva e o sistema imune do hospedeiro}

Os parasitos do gênero Leishmania possuem duas formas evolutivas, uma forma flagelada extracelular, a promastigota, encontrada no hospedeiro invertebrado e uma forma intracelular obrigatória, a amastigota, encontrada nas células do sistema mononuclear fagocitário do hospedeiro vertebrado.

Estas células parasitadas podem atuar como apresentadoras de antígenos para as células $\mathrm{T}$; assim como podem ser ativadas, desencadeando mecanismos microbicidas com potencial para destruir a Leishmania (Hall \& Titus, 1995). Tem sido demonstrado, em modelos experimentais, que a presença da saliva inativa estas funções do macrófago, como uma inibição seletiva, uma vez que o macrófago não perde sua habilidade de regular a expressão MHCIl da superfície celular (Mukbel et al., 2007). O componente principal responsável por esta inativação do macrófago é o maxadilan, capaz de inibir a proliferação de células $T$ e a hipersensibilidade tardia. Além disso, o maxadilan diminuiu a expressão de receptores de TNF-a em macrófagos, a produção de citocinas do tipo Th1 e aumenta a expressão de citocinas relacionadas à resposta Th2. O efeito vasodilatador do maxadilan pode explicar porque os mesmos vetores e parasitos podem causar uma diversidade de formas clinicas da doença em regiões diferentes (Cruz et al., 2005). Já em relação ao Velho Mundo, isto não está bem esclarecido, uma vez que os Phlebotomus possuem adenosina 
e um precursor de 5'AMP ao invés de maxadilan. A adenosina possui propriedades anti-inflamatórias, aumenta a produção de citocinas Th2 e junto com a inosina diminui as citocinas Th1. Lu. longipalpis e P. papatasi possuem hialuronidase, mas a sua função ainda não está bem esclarecida, o que se sabe é que esta enzima tem funções de estimular a produção de iNOS pelos macrófagos e aumentar citocinas Th1 (Moro \& Lerner, 1997; Rittig \& Bogdan, 2000; Kamhawi, 2000; Sousa et al., 2001; Vannier-Santos et al., 2002, Cruz et al., 2005). Os mecanismos utilizados pelos componentes da saliva para modular a resposta imune do hospedeiro ainda não são bem claros. Observou-se uma ação da saliva direta em células do tecido dérmico da ovelha de camundongos, tanto in vivo como in vitro, independente dos animais estarem infectados por Leishmania e estes efeitos era relacionado com a produção de IL-4, citocina de resposta Th2 (Titus, 1998). Em células de linfonodo de camundongos BALB/C infectados com L. braziliensis na presença de saliva, foi observado também aumento de IL-4 e progressão da lesão. O bloqueio de IL-4 com a utilização de anticorpos específicos levou a ausência dos fenômenos de exacerbação da lesão (Lima \& Titus, 1996).

\subsection{A saliva do vetor como um candidato a vacina para leishmaniose}

A perspectiva mais desejável para o controle da leishmaniose seria o desenvolvimento de uma vacina eficaz.

O fato de existirem indivíduos residentes em áreas endêmicas com reação intradérmica de Montenegro positiva, e sem nunca terem apresentado 
sinais clínicos da doença, sugere que o desenvolvimento de uma resposta imune eficaz contra o parasito possa ser capaz de controlar a infecção. A exposição recorrente a picadas do inseto vetor e conseqüentemente a sua saliva torna este componente um fator promissor em busca de uma vacina eficiente (Kamhawi, 2000; Valenzuela et al., 2001).

Experimentos foram feitos utilizando-se modelos, camundongos C57BL/6 e BALB/c sensibilizados com a saliva natural ou artificialmente e, em ambos os casos, detectou-se um efeito protetor. Em camundongos BALB/c houve diminuição da lesão na orelha e em C57BL/6 o total desaparecimento da lesão. Nestes animais, anticorpos anti-saliva do vetor foram detectados, assim como citocinas responsáveis pela resposta imune celular do tipo Th1, como INF- $\gamma$ e IL-12 (Basano \& Camargo, 2004). Há um consenso sobre a proteção conferida pela pré-exposição às proteínas da saliva, assim uma possível atuação dela como adjuvante em uma vacina tem motivado uma série de pesquisas na área (Kamhawi, 2000).

Há diversos relatos que mostram a utilização tanto de antígenos purificados como totais de saliva, porém um dos mais recentes e promissores é um estudo desenhado em cães imunizados com promastigotas mortas de L. (V.) braziliensis e saliva. Esta imunização foi capaz de proteger $50 \%$ dos da amostragem sendo que o perfil da resposta imune induzida nestes casos foi aparentemente protetor, visto que foi similar àquele observado em indivíduos curados de leishmaniose, com participação de células CD8 ${ }^{+}$, produção de níveis consideráveis de IFN- $\gamma$ e na ausência de IL-4 (Giunchetti et al., 2008). 


\subsection{Justificativa}

Deve ser ressaltado, que a grande maioria dos resultados obtidos em relação aos efeitos da saliva do vetor na infectividade dos parasitos do gênero Leishmania, descritos acima, foram obtidos utilizando-se o modelo de infecção por L. major, espécie encontrada apenas no Velho Mundo e glândulas salivares de insetos colonizados. No entanto, o papel da saliva nas infecções causadas por L. (L.) amazonensis tem nos despertado um interesse especial, uma vez que esta espécie de parasito é responsável por um espectro de manifestações clínicas como a leishmaniose cutânea localizada, leishmaniose cutânea disseminada e leishmaniose cutânea difusa, a qual representa o pólo anérgico de resposta do hospedeiro e constitui forma grave da doença em nosso país. Além disto, a falta de relatos sobre os efeitos da saliva de insetos capturados, nos despertou interesse adicional, uma vez que o seu efeito na infectividade do parasito poderia se aproximar mais ao que realmente ocorre na infecção natural por Leishmania. 
OBJETIVOS 


\section{OBJETIVOS}

Avaliar em camundongos C57BL/6 inoculados com formas promastigotas de Leishmania (Leishmania) amazonensis na ausência e na presença de extrato de glândula salivar de Lutzomyia longipalpis capturado em campo e colonizado em laboratório:

1 - Evolução do tamanho da lesão;

2 - Resposta inflamatória aguda e crônica no ponto de inoculação;

3 - Fenótipo das células inflamatórias na fase aguda e crônica da infecção;

4 - Perfil da produção de citocinas em sobrenadante de cultura de células de linfonodo de drenagem. 


\section{MATERIAIS E MÉTODOS}




\section{MATERIAIS E MÉTODOS}

\subsection{Animal}

Foram utilizados camundongos isogênicos da linhagem C57BL/6, fêmeas, com idade de 6 a 8 semanas, fornecidos pelo Centro de Bioterismo da Faculdade de Medicina da Universidade de São Paulo e mantidos no Biotério Experimental do Instituto de Medicina Tropical, que cedeu espaço para o desenvolvimento do projeto.

\subsection{Parasito}

Foram utilizadas formas promastigotas de Leishmania (Leishmania) amazonensis (cepa MHOM/BR/73/M2269) isoladas de caso humano de leishmaniose cutânea no Pará, classificada por anticorpos monoclonais e isoenzimas no Instituto Evandro Chagas, Belém, Brasil. A manutenção da cepa foi feita com a inoculação do parasito nas patas traseiras de camundongos BALB/c e com repiques a cada dois meses. Para os experimentos, parasitos foram purificados das lesões das patas, e cultivados em meio RPMI 1640 (Cultilab) com 10\% de soro fetal bovino inativado pelo calor (marca), $10 \cdot \mathrm{g} / \mathrm{mL}$ de gentamicina e $100 \mathrm{Ul} / \mathrm{mL}$ de penicilina. Esta cultura foi mantida em estufa BOD (Fanem) a $26^{\circ} \mathrm{C}$. Foram utilizados parasitos na fase estacionária de crescimento para a inoculação, do quinto ao sexto dia de cultivo (fase infectiva), após 2 a 3 passagens em cultura (Sacks \& Perkins, 1985). Os parasitos foram lavados com salina tamponada com fosfato $0,01 \mathrm{M}$ 
pH 7,2 (PBS) estéril, a concentração de parasitos ajustada para $10^{6} / \mathrm{mL}$, sendo $50 \mu l$ utilizado para a inoculação subcutânea no coxim plantar traseiro dos camundongos. Os diferentes grupos experimentais foram inoculados com os parasitos na ausência ou presença do equivalente a meio par de glândula salivar de Lu. longipalpis oriundo de colônia ou captura no campo. Grupos controles foram inoculados com meio par de glândula salivar de Lu. longipalpis oriundo de colônia ou captura no campo e PBS estéril na ausência de parasitos.

\subsection{Glândula Salivar}

As glândulas salivares de Lutzomyia longipalpis foram gentilmente cedidas pelo Laboratório de Entomologia Médica do Centro de Pesquisa Reneé Rachou - FIOCRUZ, Belo Horizonte (MG), através da colaboração do Dr. Paulo F.P. Pimenta. As fêmeas de Lu. Longipalpis, colonizadas em laboratório e capturadas em campo, ambas da região da Gruta da Lapinha em Minas Gerais, forma imobilizadas em freezer a $-20^{\circ} \mathrm{C}$ por dois minutos. As glândulas salivares foram obtidas por dissecação com o auxílio de uma lupa, um par de estiletes comuns e um outro par de estiletes confeccionados com agulhas para servirem de coletores. As fêmeas foram colocadas em lâmina com uma gota de PBS pH7,2 sendo a região do tórax levemente pressionada por um estilete e outro pressionando levemente os olhos, somente para dar apoio. Os corpos gordurosos, quando presentes, foram retirados com o auxílio dos estiletes. Após a dissecação, as glândulas foram retiradas e acondicionadas em microtubos de polipropileno de $1,5 \mathrm{~mL}$ e mantidas em 
freezer $-80^{\circ} \mathrm{C}$ até $\mathrm{O}$ momento do uso. $\mathrm{O}$ material foi encaminhado para o Laboratório de Patologia de Moléstias Infecciosas da FMUSP em garrafa de criopreservação.

O extrato de glândula salivar foi preparado através de congelamento em nitrogênio líquido e descongelamento em temperatura ambiente por três vezes consecutivas e, posteriormente, passada em um agitador de tubos (vortex) para homogeneização do lisado. A quantificação de proteínas mostrou que um par de glândula salivar de Lu. longipalpis equivale a aproximadamente $5 \mu \mathrm{g} / \mathrm{mL}$ de proteína. Portanto, ao utilizarmos o equivalente a meio par de glândula por animal inoculou-se em torno de $2,5 \mu \mathrm{g} / \mathrm{mL}$ de proteína por animal. O extrato de glândula salivar foi adicionado à suspensão de parasitos no momento da inoculação.

\subsection{Efeito do Extrato de Glândula Salivar na infecção por L. (L.) amazonensis:}

\subsubsection{Protocolo experimental}

Para este estudo foram utilizados seis grupos experimentais, sendo cada um formado por 10 animais/tempo de infecção, inoculados no coxim plantar de ambas as patas traseiras e nas orelhas com formas promastigotas de L. (L.) amazonensis na ausência e na presença de extrato de glândula salivar de Lu. longipalpis colonizada e capturada. Animais controles foram inoculados apenas com o extrato de glândula salivar de Lu. longipalpis colonizada e capturada ou PBS estéril (Quadro1). Os tamanhos das lesões 
das patas e das orelhas foram avaliados semanalmente até o sexagésimo dia de infecção utilizando-se um paquímetro. Os animais dos diferentes grupos experimentais foram sacrificados por deslocamento cervical após 1, 7, 30 e 60 dias de infecção.

\begin{tabular}{c|c|c|c|c}
\hline \hline $\begin{array}{c}\text { Grupos } \\
\text { experimentais }\end{array}$ & 24 horas & 7 dias & 30 dias & 60 dias \\
\hline \hline P+EGS-col & 10 & 10 & 10 & 10 \\
\hline P+EGS-cap & 10 & 10 & 10 & 10 \\
\hline$P$ & 10 & 10 & 10 & 10 \\
\hline EGS-col & 10 & 10 & 10 & 10 \\
\hline EGS-cap & 10 & 10 & 10 & 10 \\
\hline PBS & 10 & 10 & 10 & 10 \\
\hline
\end{tabular}

Quadro 1 - Protocolo experimental com o número de animais utilizados por grupo experimental, inoculados com Parasito + Extrato de Glândula Salivar

de Lu. longipalpis de colônia (P+EGS-col), com Parasito + Extrato de Glândula Salivar de Lu. longipalpis de captura (P+EGS-cap), com Parasitos (P), com Extrato de Glândula Salivar de Lu.longipalpis de colônia (EGS-col), com Extrato de Glândula Salivar de Lu. longipalpis de captura (EGS-cap) e com tampão (PBS).

Para estudo histopatológico, fragmentos de pele do ponto de inoculação no coxim plantar foram colhidos com Punch (Biopsy punch Stiefel) com o auxílio de pinça dente de rato e tesoura de íris ponta curva. Os fragmentos foram mergulhados em solução de formaldeído $10 \%$ em tampão fosfato 0,01M pH7,4 e processados pelas técnicas usuais de microscopia de luz.

Para a caracterização do fenótipo celular as células inflamatórias envolvidas na lesão de pele, as orelhas foram coletadas e mergulhadas em álcool $70 \%$ sob agitação por 5 minutos para desinfecção e posteriormente as faces ventral e dorsal foram separadas para recuperação de células segundo (Belkaid et al., 1996). 
Após a retirada dos fragmentos dos pontos de inoculação do coxim plantar e das orelhas, foi feita a assepsia dos animais com álcool 70\% e, em seguida, os linfonodos de drenagem do ponto de inoculação do coxim plantar traseiro (linfonodos poplíteos) foram retirados para posterior cultura de células, para avaliar a produção de citocinas.

\subsection{Avaliação da evolução do tamanho da lesão da orelha}

A dinâmica do desenvolvimento da lesão no tecido dérmico das orelhas dos camundongos inoculados com o parasito, na ausência e na presença dos diferentes extratos de glândulas salivares, de captura em campo e de colônia, foi avaliada quinzenalmente até o sexagésimo dia de infecção. Mediu-se a espessura do nódulo das lesões, com o auxílio de um paquímetro $0,01 \mathrm{~mm}$ (Mitutoyo - Brasil).

\subsection{Avaliação da evolução do tamanho da lesão da pata}

O tamanho da lesão foi avaliado pelo inchaço das patas, através da diferença das medidas da espessura da pata inoculada com o parasito na ausência e na presença dos diferentes extratos de glândulas salivares, de captura em campo e de colônia e seus respectivos controles. Esta avaliação foi feira a cada 15 dias até o sexagésimo dia de infecção com o auxílio de um paquímetro (Mitutoyo - Brasil). 


\subsection{Caracterização do fenótipo das células nas lesões cutâneas}

Após 1, 7 e 60 dias de infecção, os animais foram sacrificados, as orelhas coletadas e mergulhadas em álcool $70 \%$ sob agitação por 5 minutos. Depois de secas em temperatura ambiente, os folhetos ventral e dorsal foram separados com o auxilio de duas pinças e lupa. As faces dérmicas foram depositadas em superfície de $2 \mathrm{~mL}$ de meio de cultura RPMI completo por 6 horas em estufa $\mathrm{CO} 237^{\circ} \mathrm{C}$. Foram utilizados tubos ou placa de polipropileno para evitar a adesão de macrófagos.

Após este período, os meios foram recolhidos em pool/grupo experimental utilizando tubos Falcon de $50 \mathrm{ml}$ em banho de gelo e centrifugados sob refrigeração por 10 minutos a $1.300 \mathrm{rpm}$. As células foram lavadas em PBS estéril, e após contagem, sua concentração foi ajustada para o equivalente a $10^{5}$ células/100 $\mu \mathrm{L}$. Uma alíquota de amostra de cada grupo experimental foi citocentrifugada, esfregaços foram feitos e corados pelo Giemsa, sendo a porcentagem de células polimorfonucleares e mononucleares estimadas pelo exame em microscópio de luz.

Em $100 \mu \mathrm{l}$ da suspensão celular em tampão PBS 0,5\% BSA foi adicionado $1 \mu \mathrm{l}$ dos seguintes anticorpos: FITC anti-Ly-6G (RB6-8C5, Pharmingen-USA), PE anti-F4/80 (A3-1, Serotec-UK), FITC anti-CD3ع chain, PerCP anti-CD4 L3T4, anti-CD8a Ly-2 (Pharmingen-USA). Os controles isotípicos foram IgG2a e IgG2b de rato (Pharmingen-USA); seguida de incubação por 30 minutos em temperatura ambiente.

Posteriormente, adicionou-se $300 \mu$ de solução de lise, a suspensão celular foi homogeneizada em vórtex e incubada por 10 minutos em 
temperatura ambiente. $300 \mu \mathrm{l}$ de PBS 0,5\% BSA foi adicionado e após homogeneização os tubos foram centrifugados sob refrigeração por 10 minutos a 1300rpm.

A suspensão foi lavada por mais 1 vez em PBS $0,5 \%$ BSA, o sobrenadante foi desprezado e adicionou-se $300 \mu$ l de solução fixadora (Macs Facs Fix, Pharmingem-USA). A leitura foi feita em citômetro de fluxo (FACSCalibur - Software Cellquest). Para cada amostra, $10^{3}$ células foram analisadas.

\subsection{Preparo do antígeno de L. (L.) amazonensis para estímulo das culturas de células de linfonodo poplíteo.}

Foram isoladas formas amastigotas de $L$. (L.) amazonensis, em meio de cultura RPMI suplementado com $10 \%$ de soro fetal bovino inativado pelo calor, $2 \%$ de urina humana, $10 \mu \mathrm{g} / \mathrm{mL}$ de gentamicina e $100 \mathrm{Ul} / \mathrm{mL}$ de penicilina, oriundas de infecção crônica na pata traseira de camundongo BALB/c. Após duas a três passagens desta cultura, as formas promastigotas, em fase estacionária de cultivo, foram transferidas para tubos com fundo cônico (Falcon) de $50 \mathrm{~mL}$, lavadas três vezes em solução salina tamponada estéril através de centrifugação a $3.000 \mathrm{rpm}$ a $4^{\circ} \mathrm{C}$ durante 10 minutos. Após ser retirado todo o resíduo líquido do tubo, estes foram estocadas em freezer à $-80^{\circ} \mathrm{C}$ na forma de precipitado (pellet).

Para preparo do antígeno, este precipitado contendo as formas promastigotas passou por um processo de congelamento e descongelamento com nitrogênio líquido e temperatura ambiente por três vezes consecutivas. 
Foi realizada nova centrifugação a $12.000 \mathrm{rpm}$ por 30 minutos a $4^{\circ} \mathrm{C}$ e armazenou-se o sobrenadante a $-80^{\circ} \mathrm{C}$. Uma alíquota foi utilizada para a dosagem de proteínas pelo método de Bradford (Bio-Rad Protein Assay, Hercules, USA).

\subsection{Cultura de células de linfonodo poplíteo para dosagem de citocinas}

Para coleta dos linfonodos poplíteos de drenagem, os animais foram colocados em álcool $70 \%$ por 15 minutos no fluxo laminar. O tecido cutâneo entre o tornozelo e a região inguinal foi rebatido para posterior exposição do linfonodo poplíteo. Todos os linfonodos de um mesmo grupo experimental foram colocados em uma mesma placa de Petri contendo meio de cultura RPMI 1640 (Cultilab) com 10\% de soro fetal bovino estéril (Laborclin) inativado pelo calor, $10 \mu \mathrm{g} / \mathrm{mL}$ de gentamicina e $100 \mathrm{Ul} / \mathrm{mL}$ de penicilina e mantidos em banho de gelo. Os linfonodos foram macerados em uma peneira de células (Cell Strainer 70 $\mu \mathrm{m}$ BD Falcon) com o auxílio de um êmbolo de seringa estéril de $5 \mathrm{~mL}$. Esta suspensão celular foi colocada em tubo cônico de plástico de $15 \mathrm{~mL}$ e mantida refrigerada. Para avaliação da concentração e viabilidade das células obtidas, utilizou-se Azul de Tripan na diluição de 1/100 e câmara de Neubauer. A concentração do pool de células do grupo P, P+EGS-captura, P+EGS-colônia e seus respectivos controles foram ajustadas para $10^{6} / \mathrm{mL}$.

$100 \mu \mathrm{l}$ de cada suspensão celular contendo $10^{5}$ células foi adicionada em cada cavidade de placa de 96 cavidades para cultura de célula (TPP-92096). 
A placa de cultura foi dividida em três grupos, sendo um grupo estimulado com antígeno específico (1), o outro com concanavalina A - controle positivo (2) e o último sem estímulo - controle negativo (3).

Para os grupos 1 e 2 foi adicionado a suspensão celular $100 \mu l$ de antígeno específico de L. (L.) amazonensis e concanavalina A (SigmaAldrich), respectivamente; na concentração de $1 \mu \mathrm{g}$ por cavidade. No grupo 3

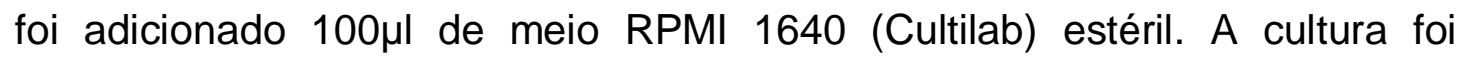
mantida por 48 horas a $37^{\circ} \mathrm{C}, 5 \% \mathrm{CO}_{2}$ em estufa de cultura de células (Revco).

Passado este período, as placas foram centrifugadas a $1.300 \mathrm{rpm}$ por 10 minutos para obtenção do sobrenadante da cultura. Foram feitas alíquotas em tubos de polipropileno de $2 \mathrm{~mL}$ dos diferentes grupos experimentais para posteriores dosagens de citocinas. Retirou-se, de cada cavidade, em torno de $180 \mu \mathrm{l}$ do sobrenadante. Este processo foi feito com a placa e as alíquotas depositadas em banho de gelo e, em seguida, as amostras foram estocadas em freezer a $-80^{\circ}$.

3.10. Determinação das concentrações de citocinas (IL-2, IL-4, IL-10, IL-12 e INF- $\gamma$ ) nos sobrenadantes das culturas de células de linfondo

As concentrações de citocinas (IL-2, IL-4, IL-10, IL-12 e INF- $\gamma$ ) foram determinadas nos sobrenadantes das culturas de células dos linfonodos coletados dos diferentes grupos experimentais. Para a dosagem das citocinas utilizou-se Kit comercial imunoenzimático de ELISA (BD OptEIA ${ }^{\mathrm{TM}}$ 
Set Mouse Biosciences, San Diego, CA) seguindo as orientações do fabricante. As concentrações foram determinadas com base em padrões recombinantes e com suas concentrações pré-determinadas pelo fabricante. Para montagem das curvas padrão e obtenção dos resultados das concentrações das amostras foi feita análise de regressão linear em programa Excel do Office 2003. Os limites de detecção para as concentrações das citocinas pesquisadas foram: IL-2 (200 - 3,1pg/mL), IL-4 (500 - 7,8 pg/mL), IL-10 (2000 - 31,3 pg/mL), IL-12 (4000 - 62,5 pg/mL) e INF$\gamma(200-3,1 \mathrm{pg} / \mathrm{mL})$.

Brevemente, as placas de 96 poços de alta afinidade (Costar Cambridge, MA, EUA) foram sensibilizadas com o anticorpo monoclonal de captura diluído em seus respectivos tampões, conforme concentrações descritas pelo fabricante (para IL-2, IL-4, IFN- $\gamma$ em tampão carbonato $0,1 \mathrm{M}$ pH 9,5 e para IL-10 e IL-12 em tampão fosfato de sódio $0,2 \mathrm{M}$ pH 6,5) e incubadas por aproximadamente 18 horas em câmara úmida a $4^{\circ} \mathrm{C}$. Passado este período, as mesmas foram lavadas por três vezes com tampão de lavagem PBS 0,05\% de Tween 20 (PBS-T), bloqueadas com o tampão diluente de ensaio $(100 \mu \mathrm{L}$ de PBS acrescido de $10 \%$ de soro fetal bovino $\mathrm{pH} 7,0$ ) e incubadas durante uma hora a temperatura ambiente em câmara úmida. Após esta fase, as placas foram novamente lavadas por três vezes e, em seguida, $100 \mu \mathrm{L}$ das amostras (sobrenadantes das culturas) foram adicionadas em triplicata, assim como das respectivas diluições das curvas padrões, em duplicata, conforme orientações do fabricante. A seguir, as placas foram incubadas duas horas a temperatura ambiente em câmara úmida. $\mathrm{Na}$ etapa seguinte, as placas foram lavadas por quatro vezes com 
tampão de lavagem, e após a adição do conjugado $(100 \mu l$ de solução do anticorpo de detecção + estreptavidina conjugada à peroxidase) foram incubadas durante uma hora a temperatura ambiente em câmara úmida. Seguindo-se cinco lavagens, $100 \mu \mathrm{L}$ de solução substrato (TMB: 3,3',5,5' tetramethylbenzidine + peróxido de hidrogênio - na proporção de 1/1) foi adicionado nos poços das placas. Por fim, as placas foram incubadas por trinta minutos protegidas da luz e, passado este período, a reação foi bloqueada com $50 \mu \mathrm{L}$ de ácido sulfúrico $2 \mathrm{~N}$. A leitura foi feita em leitor de placa de ELISA (Multiskan Ex - Uniscience) utilizando filtro de 450nm e para correção da leitora, filtro de 570nm.

Os resultados foram expressos pela média \pm desvio padrão das triplicatas.

\subsection{Analise Estatística}

Os testes estatísticos foram feitos utilizando o programa de computador SigmaStat 3.1 (Statistical Software). Foi utilizado Teste t de Student para avaliar diferenças significantes entre os grupos experimentais. Nos dados não paramétricos foi usado o teste de Mann-Whitney Rank Sum para um estudo comparativo entre os grupos. Os resultados foram considerados significantes para valores de $p<0,05$. 


\section{RESULTADOS}




\section{RESULTADOS}

\subsection{Evolução do tamanho da lesão}

O tamanho das lesões causadas pela inoculação de formas promastigotas de L. (L.) amazonensis na presença ou ausência do extrato de glândula salivar de vetor capturado em campo ou colonizado aumentou com o tempo de infecção, tanto no coxim plantar como nas orelhas dos camundongos. Na infecção do coxim plantar, o grupo inoculado com parasito + extrato de glândula salivar de Lu. longipalpis de vetor de colônia teve uma lesão maior quando comparado aos grupos com parasito + extrato de glândula salivar de Lu. longipalpis de captura e somente com parasitos durante todo o período do estudo $(p<0.05)$. Já nas orelhas, não foi observada diferença significante entre os grupos experimentais, entretanto houve uma tendência de uma lesão mais evidente no grupo inoculados com o parasito + extrato de glândula salivar de colônia, enquanto os grupos inoculados com o parasito + extrato de glândula salivar de vetor capturado e somente como os parasito não mostraram diferenças (Figura 1 e 2). 


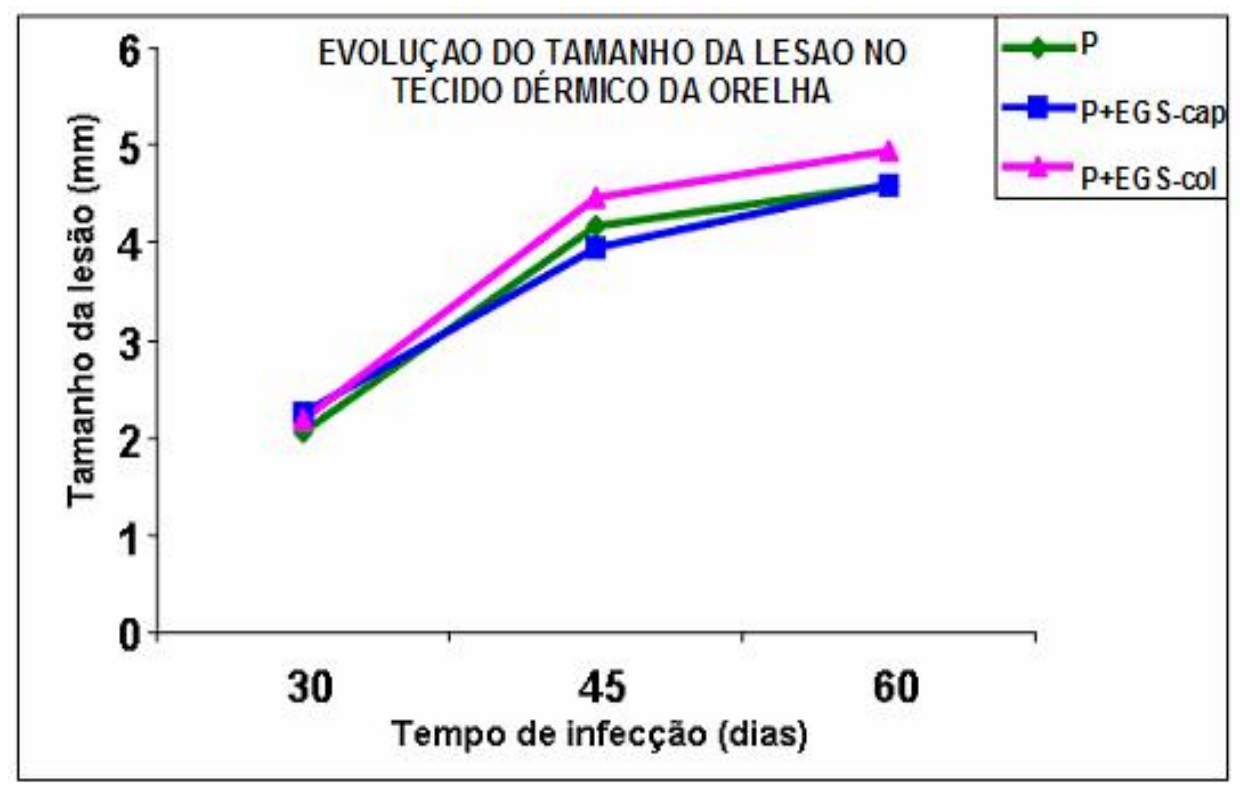

Figura 1 - Evolução do tamanho da lesão no tecido dérmico da orelha de camundongos C57BL/6 infectados com $10^{6}$ formas promastigotas de $L$. (L.) amazonensis na ausência $(P)$ e na presença de extrato de glândula salivar de Lu. longipalpis de colônia (P+EGS-col) e de captura (P+EGS-cap).

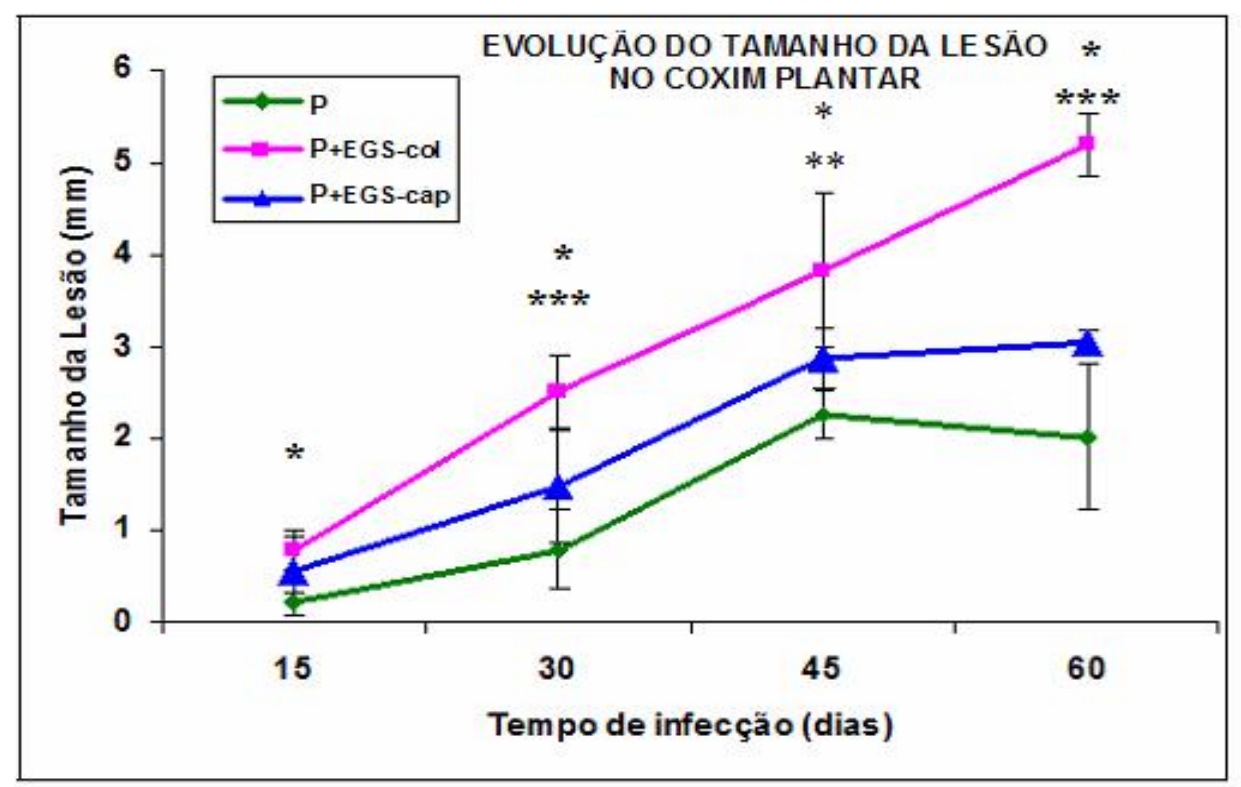

Figura 2 - Evolução do tamanho da lesão no coxim plantar traseiro de camundongos $\mathrm{C} 57 \mathrm{BL} / 6$ infectados com $10^{6}$ formas promastigotas de $L$. (L.) amazonensis na ausência $(P)$ e na presença de extrato de glândula salivar de Lu. longipalpis de colônia (P+EGS-col) e de captura (P+EGS-cap). 


\subsection{Análise histopatológica da lesão de pele do coxim plantar}

A análise do processo inflamatório desencadeado pela inoculação de formas promastigotas de $L$. (L.) amazonensis no coxim plantar traseiro de camundongos C57BL/6 na ausência ou presença do extrato de glândula salivar de Lu. longipalpis colonizados ou capturados no campo mostrou na fase aguda da infecção, 24horas, intenso infiltrado inflamatório predominantemente formado por leucócitos polimorfonucleares com presença moderada de parasitos, nos grupos P+EGS-col, P+EGS-cap e P (Figura 3). Com 7 dias de infecção, células mononucleares eram predominantes no sítio inflamatório e pareciam ser mais abundantes no grupo P+EGS-col, assim como o número de parasitos na lesão (Figura 4). Não foi observada reação inflamatória nos grupos controle, inoculados somente com o extrato de glândula salivar de inseto colonizado e capturado no campo. 

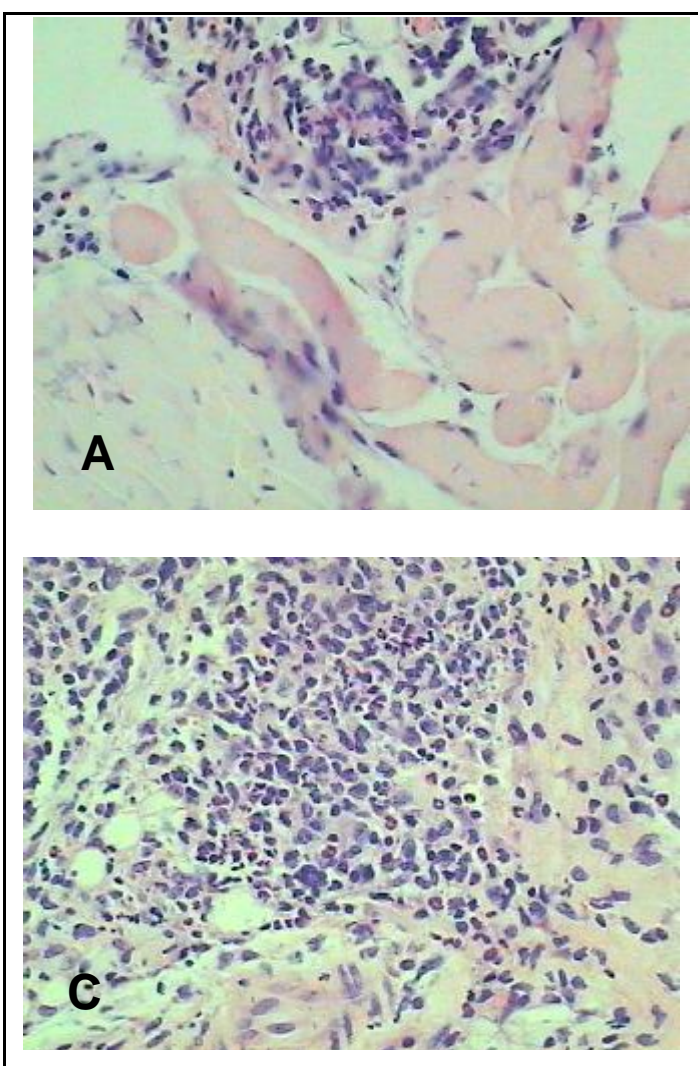

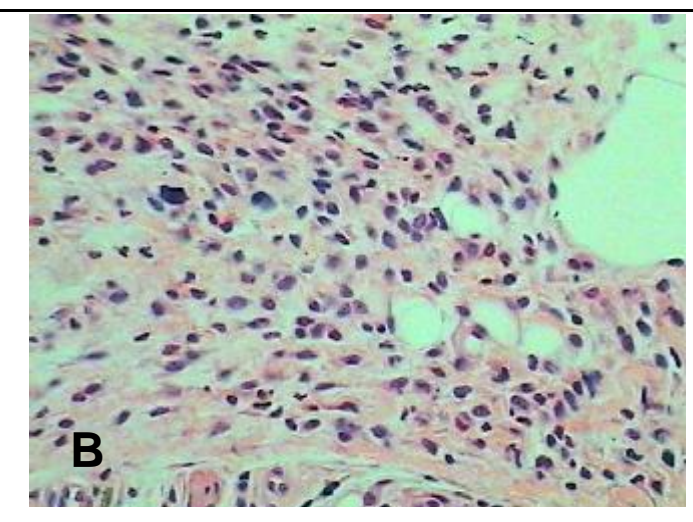

Figura 3 - Corte histopatológico do ponto de inoculação subcutâneo de promastigotas de L. (L.) amazonensis na presença do extrato de glândula salivar de Lu. longipalpis de colônia (A), de captura (B) e na ausência (C) em camundongos C57BL/6, às 24 horas de infecção (H\&E - A.O. 40X)
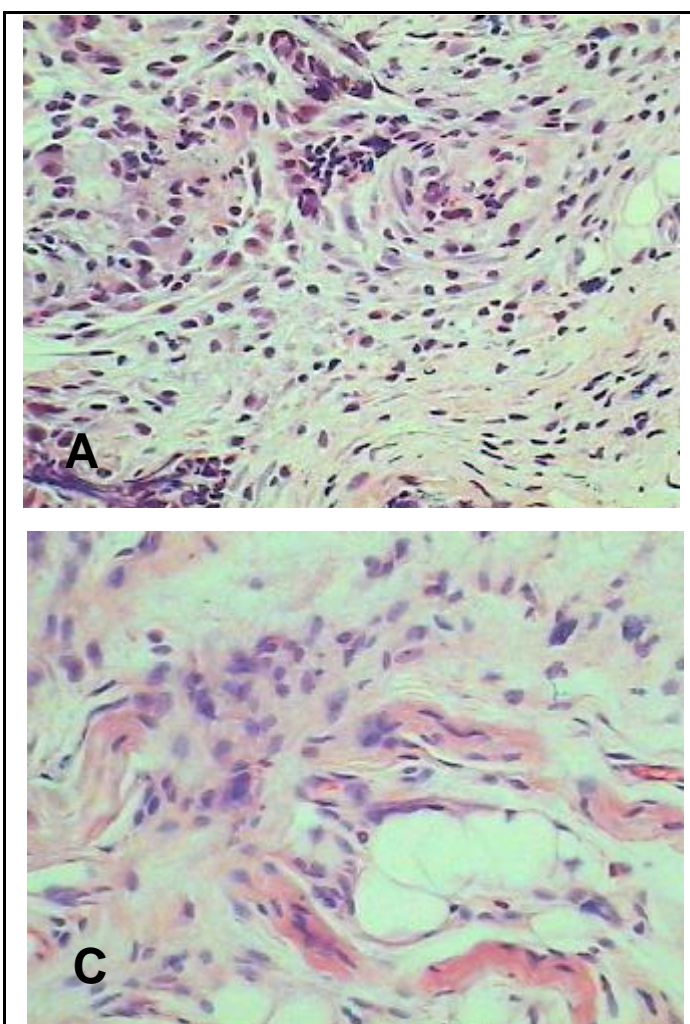

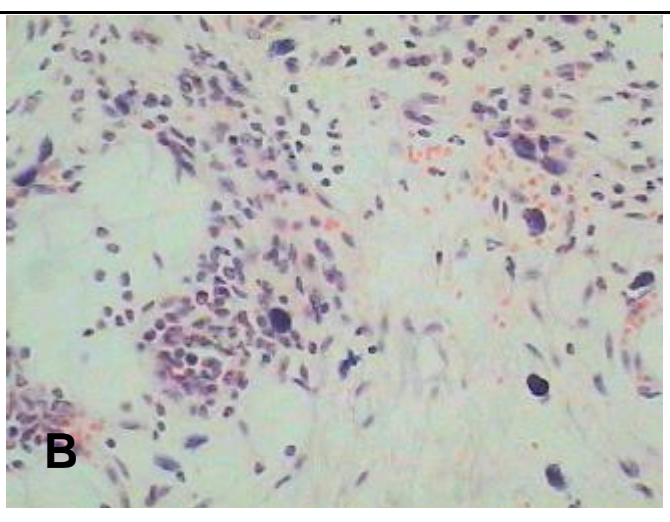

Figura 4 - Corte histopatológico do ponto de inoculação subcutâneo de promastigotas de L. (L.) amazonensis na presença do extrato de glândula salivar de Lu. longipalpis de colônia (A), de captura (B) e na ausência (C) em camundongos C57BL/6, aos 7 dias de infecção (H\&E - A.O. 40X). 
$\mathrm{Na}$ fase crônica da infecção, aos 30 e 60 dias, foi evidente a participação de infiltrado inflamatório predominante formado por células mononucleares com fagocitose de parasitos nos grupos experimentais P+EGS-col, P+EGS-cap e P. Diferença marcante foi observada aos 60 dias de infecção, quando o grupo P+EGS-col mostrava apenas a presença de macrófagos vacuolizados intensamente parasitados e os grupos P+EGS-cap e P mostravam além de macrófagos vacuolizados e parasitos, a presença de infiltrado inflamatório nodular formado por monócitos e linfócitos, e áreas focais de necrose (Figura 5).
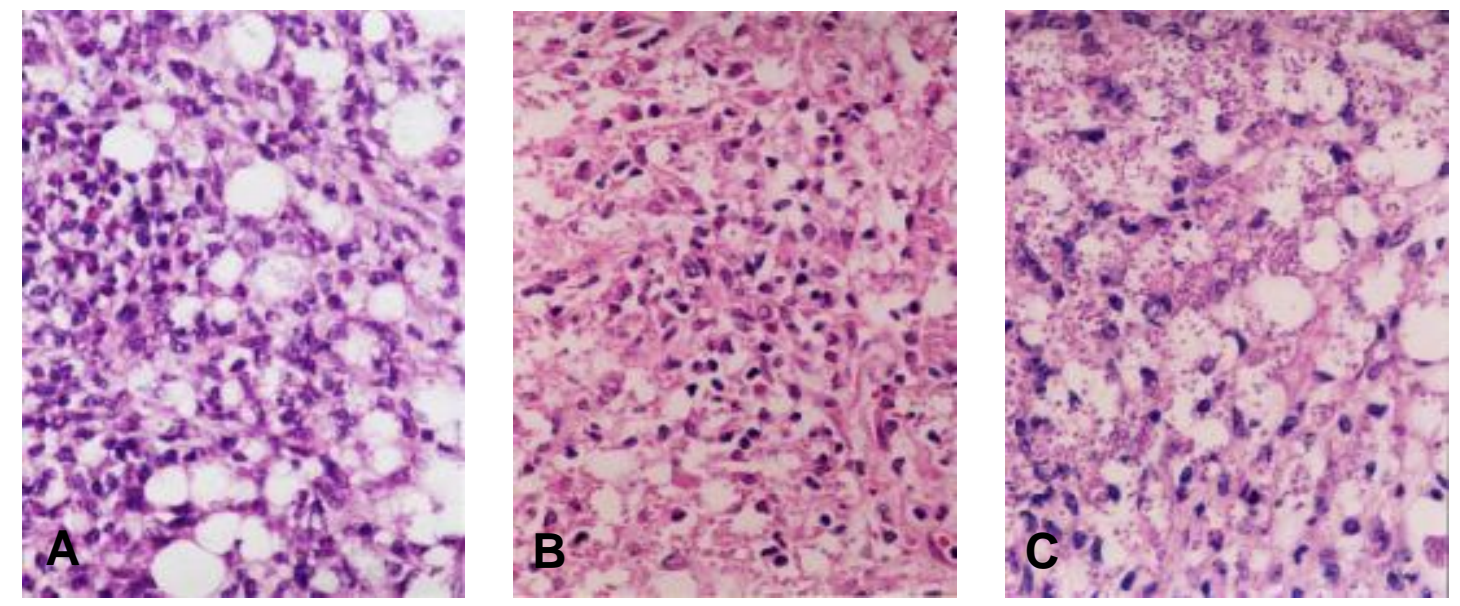

Figura 5 - Histopatologia da lesão de pele de camundongos C57BL/6 inoculados com promastigotas de $L$. (L.) amazonensis na ausência $(A)$ e na presença do extrato de glândula salivar de Lu. longipalpis de captura (B) e de colônia (C) aos 60 dias de infecção (H\&E - A.O. 40X).

\subsection{Análise histopatológica da lesão de pele da orelha}

A semelhança dos resultados encontrados no coxim plantar na fase crônica da infecção, a histologia do tecido dérmico das orelhas dos animais inoculados com o parasito na presença da saliva de colônia mostrava a presença de macrófagos com abundância de formas amastigotas de $L$. (L.) 
amazonensis. Macrófagos vacuolizados, com número menor de parasitas e áreas focais de infiltração de células mononucleares, foram observados no grupo de animais inoculados com o parasito na presença de saliva de vetor capturado no campo. Nos animais inoculados somente com o parasito, poucos macrófagos com formas amastigotas e intenso infiltrado inflamatório mononuclear caracterizou as lesões no sexagésimo dia de infecção.

\subsection{Caracterização das células recuperadas da lesão da orelha}

No primeiro dia de infecção, os animais infectados com parasitos na presença de extrato de glândula salivar mostraram um número maior de células recuperadas do tecido da derme da lesão da orelha principalmente o grupo inoculado com parasito + extrato de glândula salivar de colônia. Aos 7 dias de infecção, houve uma queda no número de células recuperadas da lesão da derme em todos os grupos experimentais. Já no $60^{\circ}$ dia pós infecção, o número de células recuperadas foi bem maior principalmente nos grupos inoculados com os extratos de glândula salivar, dentre eles o grupo inoculado com extrato de glândula salivar de colônia obteve o maior número de células recuperadas (Tabela 2). 


\begin{tabular}{c|c|c|c}
\hline \hline Grupos & 1 dia & 7 dias & 60 dias \\
\hline \hline$P$ & $17 \times 10^{5}$ & $7 \times 10^{5}$ & $38,5 \times 10^{7}$ \\
\hline P+EGS-col & $28,8 \times 10^{5}$ & $4,2 \times 10^{5}$ & $85,5 \times 10^{7}$ \\
\hline P+EGS-cap & $23,4 \times 10^{5}$ & $3,2 \times 10^{5}$ & $44,5 \times 10^{7}$ \\
\hline
\end{tabular}

Tabela 2 - Número de células recuperadas por sedimentação em meio de cultura no ponto de inoculação do tecido da derme de orelhas de camundongos C57BL/6 infectados com formas $10^{6}$ promastigotas de L.(L.) amazonensis na ausência ou na presença de extrato de glândula salivar de

Lu. longipalpis de colônia ou de captura (P, P+ESG-col e P+EGS-cap, respectivamente).

\subsection{Fenotipagem das células recuperadas da lesão da orelha}

No início da infecção (primeiro dia), observou-se uma alta porcentagem de neutrófilos nas células recuperadas da lesão da derme da orelha, principalmente no grupo inoculado somente com o parasito, seguido dos grupos inoculados com o parasito + extrato de glândula salivar de captura e de colônia. Também, pode-se observar no primeiro dia, uma expressiva porcentagem de macrófagos no grupo inoculado com parasito + extrato de glândula salivar de colônia. Baixa porcentagem de linfócitos esteve presente no tecido da derme das orelhas no primeiro dia de infecção e não mostrou diferença entre os grupos experimentais (Figura 6). No sétimo dia de infecção, observou-se uma diminuição no número de neutrófilos e um aumento no número de macrófagos das células recuperadas da lesão principalmente no grupo inoculado com parasito + extrato de glândula salivar de colônia, em relação ao primeiro dia de infecção. Uma porcentagem mais expressiva de linfócitos foi observada principalmente no grupo inoculado somente com parasitos quando comparados com os grupos inoculados com os dois tipos de extratos de glândula salivar (Figura 7). 
$\mathrm{Na}$ fase crônica de infecção, aos 60 dias, uma alta porcentagem de macrófagos principalmente no grupo inoculado com o parasito + extrato de glândula salivar de colônia seguido pelo grupo de extrato de glândula salivar de captura foi observada. Verificou-se, também, uma alta porcentagem de linfócitos $\mathrm{CD}^{+}$e $\mathrm{CD}^{+}$no grupo inoculado somente com o parasito seguido do grupo inoculado com extrato de glândula salivar de captura (Figura 8). O número de células CD8+ foi baixo e não houve diferença entre os grupos exceto no sétimo dia de infecção que o grupo inoculado somente com parasito mostrou um número mais expressivo destas células.

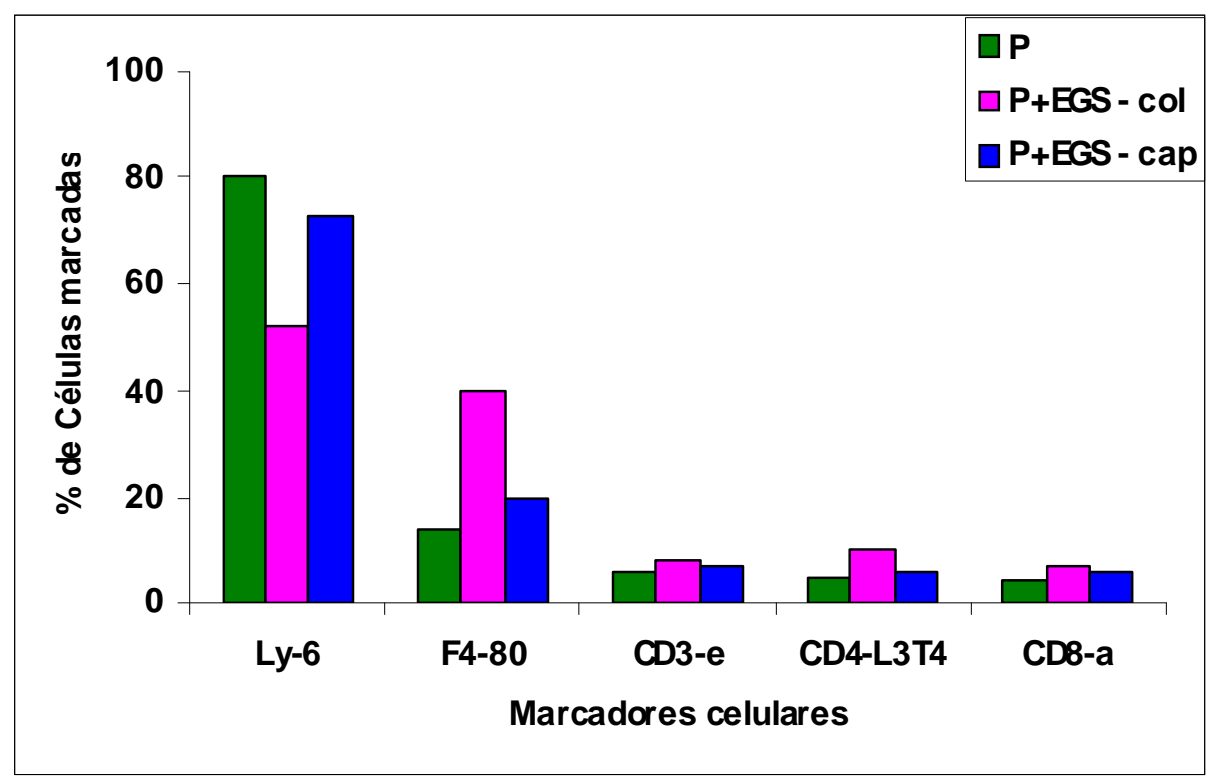

Figura 6 - Porcentagem de células marcadas pelos anticorpos monoclonais, anti-Ly-6, F4-80, CD3-e, CD4 e CD8 nas células recuperadas do tecido dérmico das orelhas de camundongos C57BL/6, 24 horas após serem infectados com $10^{6}$ promastigotas de $L$. (L.) amazonensis na ausência e na presença de extrato de glândula salivar de Lu. longipalpis de colônia ou de captura ( $\mathrm{P}, \mathrm{P}+\mathrm{ESG}$-col e P+EGS-cap, respectivamente). 


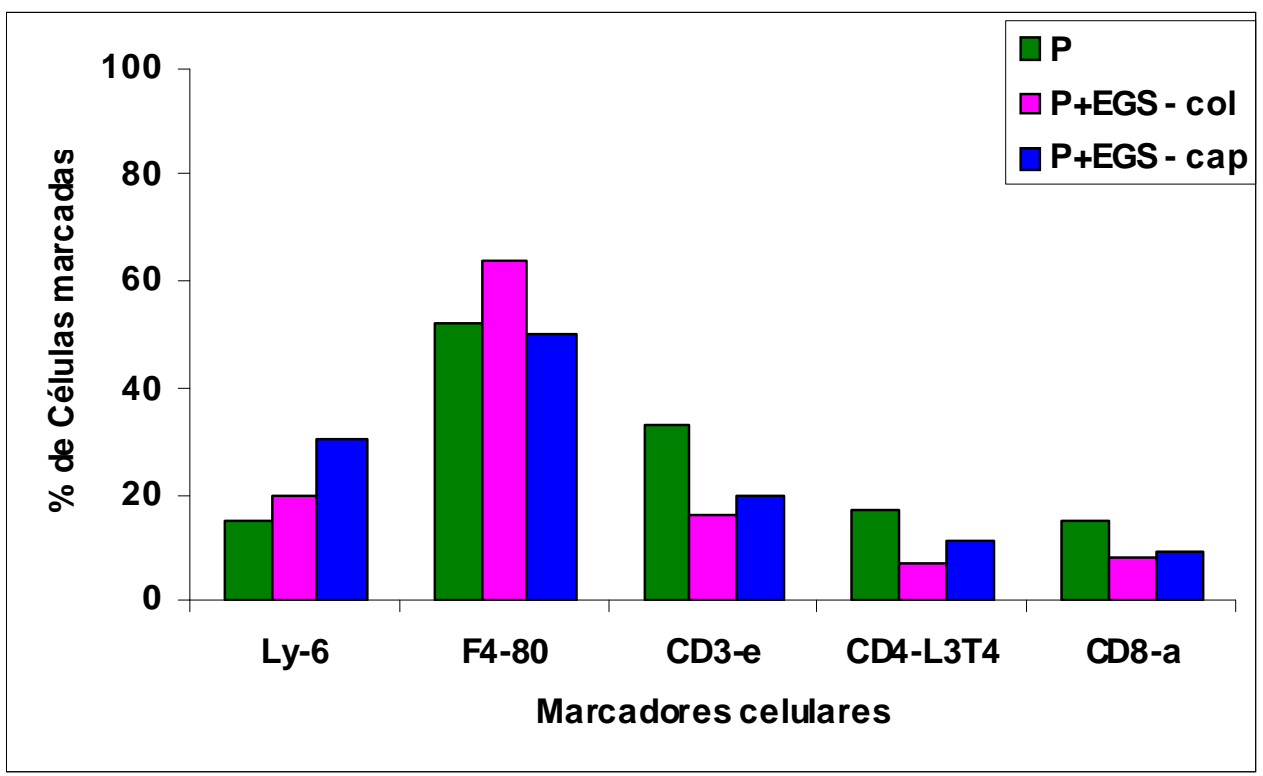

Figura 7 - Porcentagem de células marcadas pelos anticorpos monoclonais, anti-Ly-6, F4-80, CD3, CD4 e CD8 nas células recuperadas do tecido dérmico das orelhas de camundongos C57BL/6, 7 dias após serem infectados com $10^{6}$ promastigotas de $L$. (L.) amazonensis na ausência e na presença de extrato de glândula salivar de Lu. longipalpis de colônia ou de captura ( $\mathrm{P}$, $\mathrm{P}+\mathrm{ESG}$-col e P+EGS-cap, respectivamente).

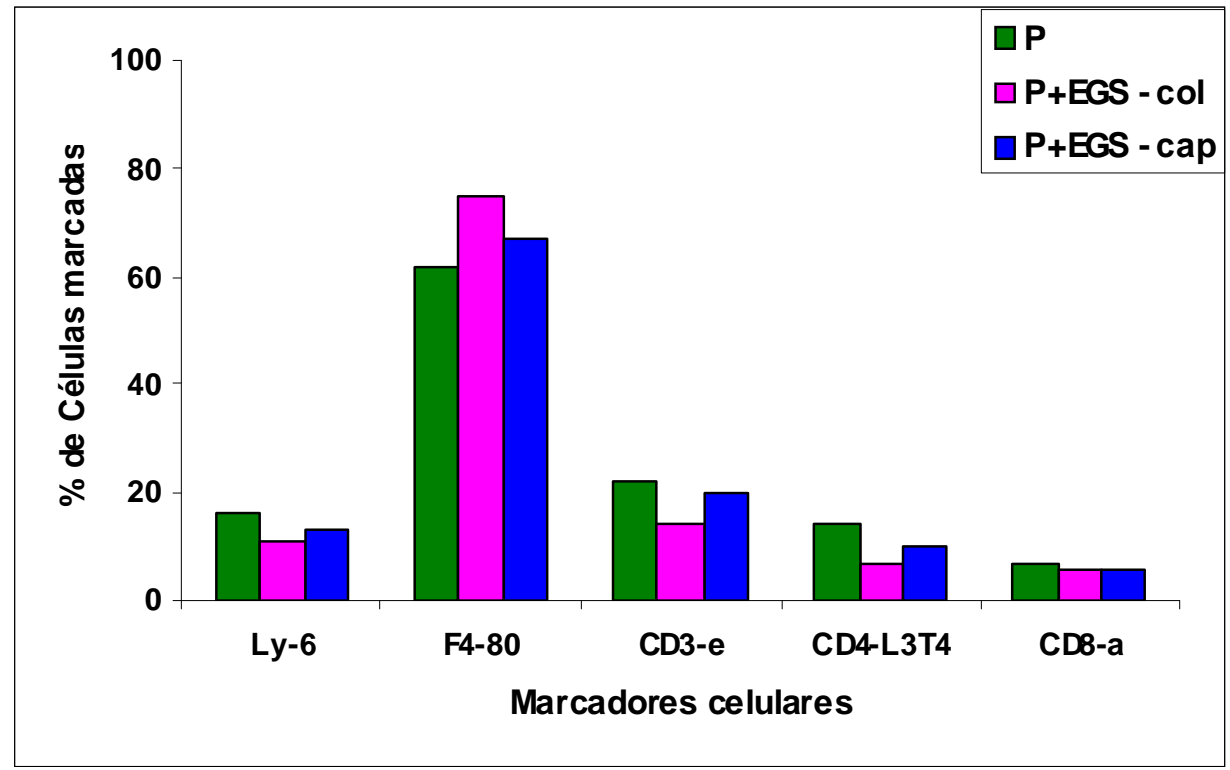

Figura 8 - Porcentagem de células marcadas pelos anticorpos monoclonais, anti-Ly-6, F4-80, CD3, CD4 e CD8 nas células recuperadas do tecido dérmico das orelhas de camundongos C57BL/6, 60 dias após serem infectados com $10^{6}$ promastigotas de $L$. (L.) amazonensis na ausência e na presença de extrato de glândula salivar de $L$ u. longipalpis de colônia ou de captura ( $P$, P+ESG-col e P+EGS-cap, respectivamente). 


\subsection{Determinação do perfil de citocinas}

O perfil de citocinas produzidas pelas células de linfonodos de drenagem de C57BL/6 infectados com formas promastigotas de L.(L.) amazonensis com ou sem o extrato de glândula salivar de Lu. longipalpis capturadas e colonizadas, e estimuladas in vitro com antígeno específico estão demonstradas nas figuras 9 - 13. No início da infecção, primeiro dia, observou-se uma expressiva produção de IL-12 com níveis altos no grupo inoculado somente com parasito $(p<0.05)$; este grupo mostrou também níveis mais elevados de IL-4 e IL-10 quando comparado com os grupos inoculados com os dois tipos de extrato de glândulas salivares estudadas $(p<0.05)$. As outras citocinas estudadas foram produzidas em menores concentrações, sendo inexpressiva a produção de IL-2 e IFN- $\gamma$. No sétimo dia de infecção, aumento nos níveis de IL-12 foi observado principalmente no grupo inoculado somente com o parasito seguido do grupo com extrato de glândula salivar de captura e depois a dos animais colonizados $(p<0.05)$. As citocinas IL-4 e IL10 se mostraram em altas concentrações em ambos os grupos inoculados com os extratos de glândula salivar quando se compara com o grupo que foi infectado somente com o parasito $(p<0.05)$. Com relação a IL-10, o grupo inoculado com extrato de glândula salivar de colônia foi o que mostrou maiores concentrações desta citocina durante a fase aguda $(p<0.05)$. Na fase crônica da infecção, trigésimo dia, a concentração de IL-12 foi menor para todos os grupos experimentais. Apesar dos baixos níveis de INF- $\gamma$ em todos os grupos experimentais, pode-se observar um aumento expressivo no grupo inoculado somente com o parasito $(p<0.05)$. Observou-se que, os grupos 
inoculados com os dois tipos de extrato de glândulas salivares, mostraram níveis de IL-4 e IL-10 aumentados durante este período de infecção, principalmente o grupo que continha o extrato de glândula salivar de colônia $(p<0.05)$. No sexagésimo dia de infecção, os níveis de INF- $\gamma$ e IL-2 tiveram aumentos expressivos principalmente no grupo infectado somente com parasito $(\mathrm{p}<0.05)$. Por outro lado, observaram-se altas concentrações de IL-4 e IL-10 nos grupos inoculados com ambos os extratos de glândulas salivares, quando comparado com o grupo infectado somente com parasito, principalmente no extrato de glândula salivar de animais colonizados $(p<0.05)$.

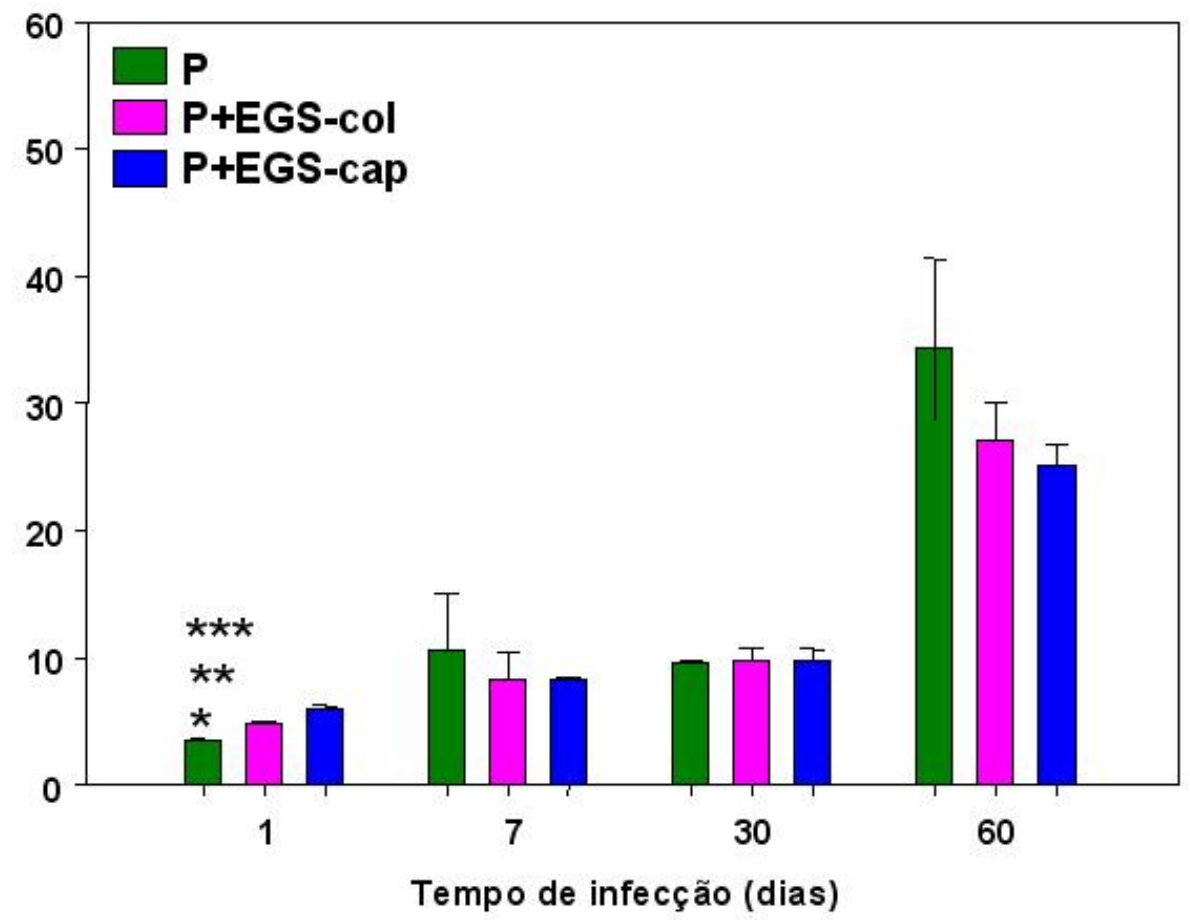

Figura 9 - Determinação da concentração de IL-2 nos sobrenadantes de cultura de células de linfonodos de drenagem de camundongos C57BL/6 infectados com $10^{6}$ formas promastigotas de $L$. (L.) amazonensis na ausência e na presença de extrato de glândula salivar de Lu. longipalpis de colônia e de captura (P, P+ESG-col e P+EGS-cap). ${ }^{*} p<0.05$ entre os grupos $P$ e $P+E G S-c o l,{ }^{* \star} p<0.05$ entre os grupos $P$ e $P+E G S-c a p,{ }^{* * *} p<0.05$ entre os grupos $P+E G S-c o l$ e $P+E G S-c a p$ 


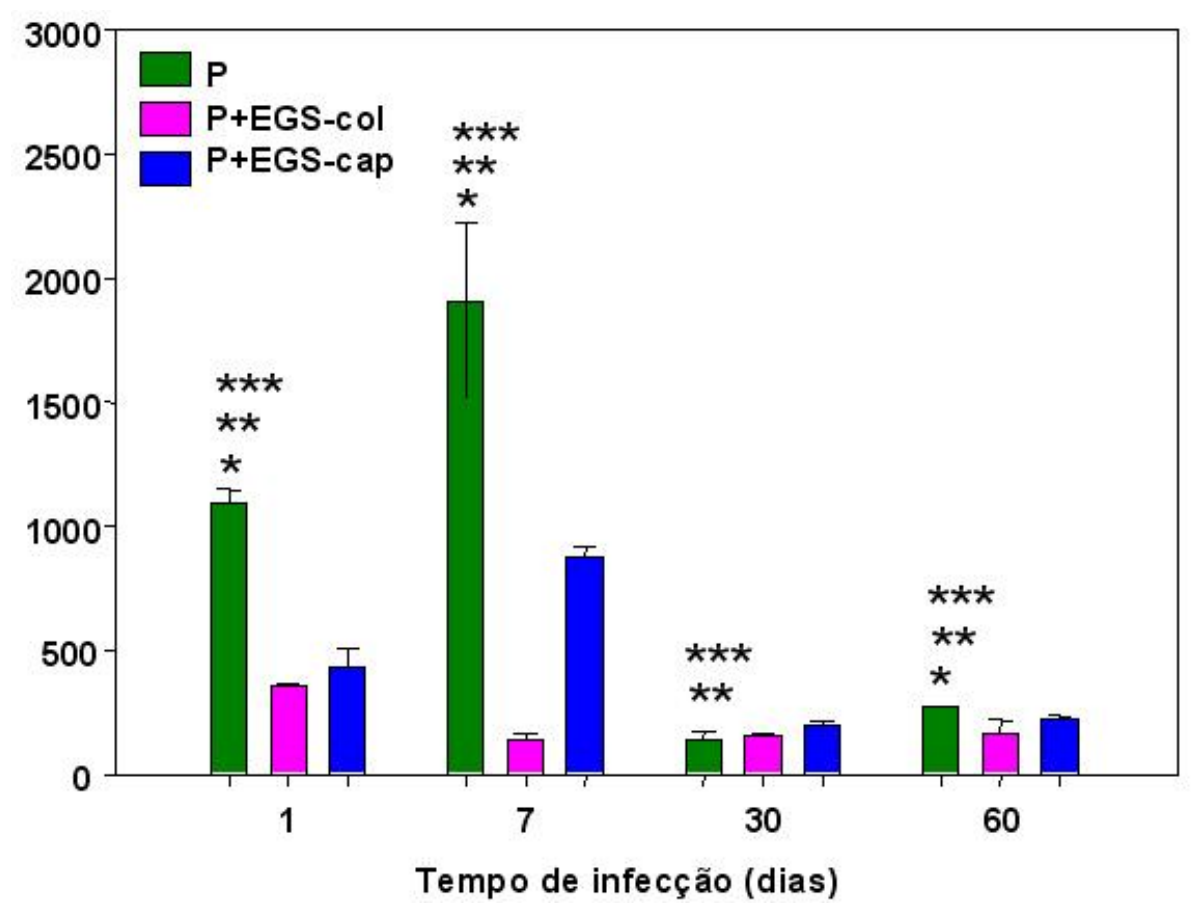

Figura 10 - Determinação da concentração de IL-12 nos sobrenadantes de cultura de células de linfonodos de drenagem de camundongos C57BL/6 infectados com $10^{6}$ formas promastigotas de $L$. (L.) amazonensis na ausência e na presença de extrato de glândula salivar de $L u$. longipalpis de colônia ou de captura (P, P+ESG-col e P+EGS-cap). * $p<0.05$ entre os grupos $\mathrm{P}$ e $P+E G S-c o l,{ }^{* *} p<0.05$ entre os grupos $P$ e $P+E G S-c a p,{ }^{* *} p<0.05$ entre os grupos P+EGS-col e P+EGS-cap 


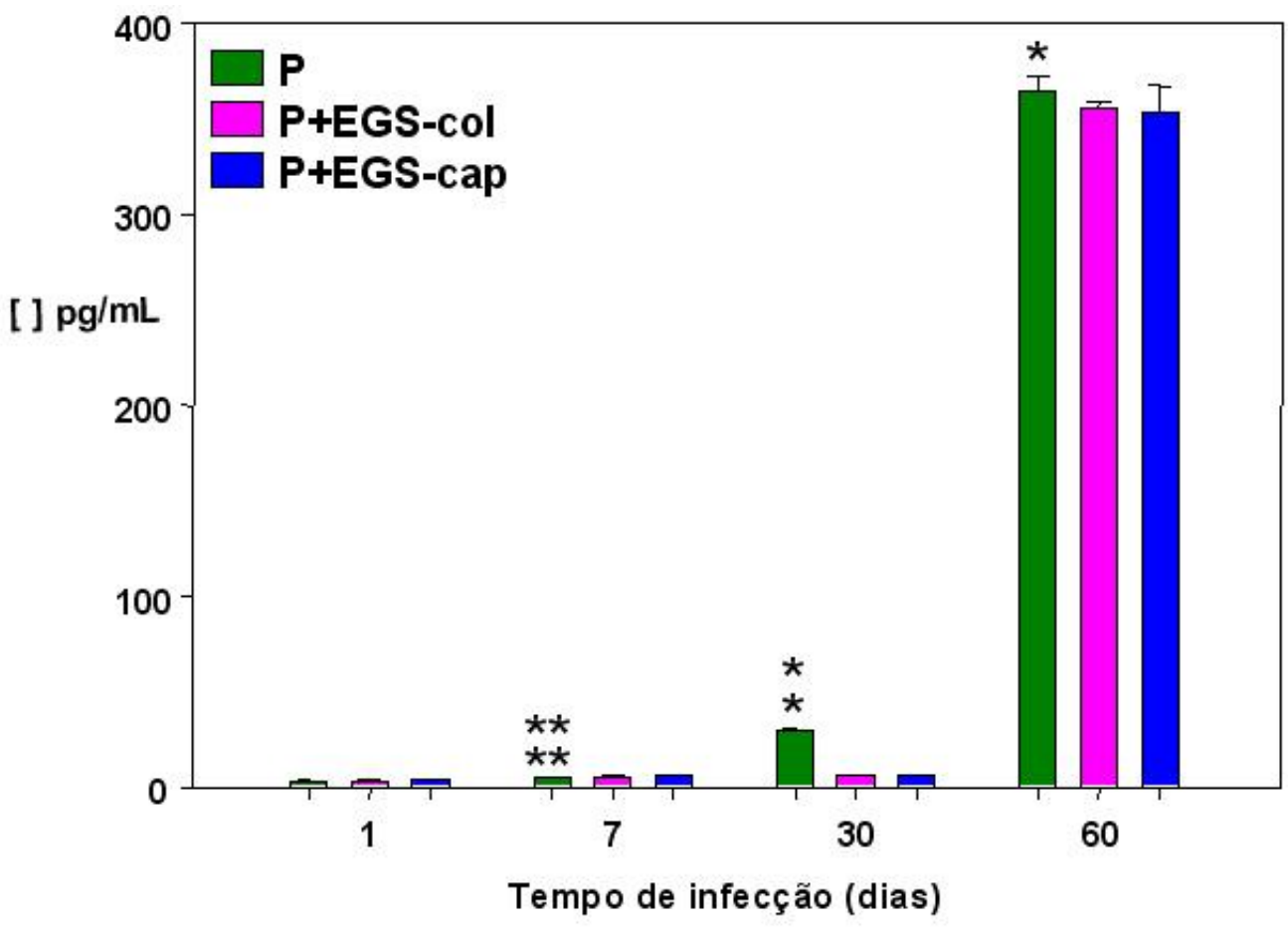

Figura 11 - Determinação da concentração de INF- $\gamma$ nos sobrenadantes de cultura de células de linfonodos de drenagem de camundongos C57BL/6 infectados com $10^{6}$ formas promastigotas de $L$. (L.) amazonensis na ausência e na presença de extrato de glândula salivar de $L u$. longipalpis de colônia ou de captura (P, P+ESG-col e P+EGS-cap). * $\mathrm{p}<0.05$ entre os grupos $\mathrm{P}$ e $P+E G S-c o l,{ }^{* *} p<0.05$ entre os grupos $P$ e $P+E G S-c a p,{ }^{* *} p<0.05$ entre os grupos P+EGS-col e P+EGS-cap 


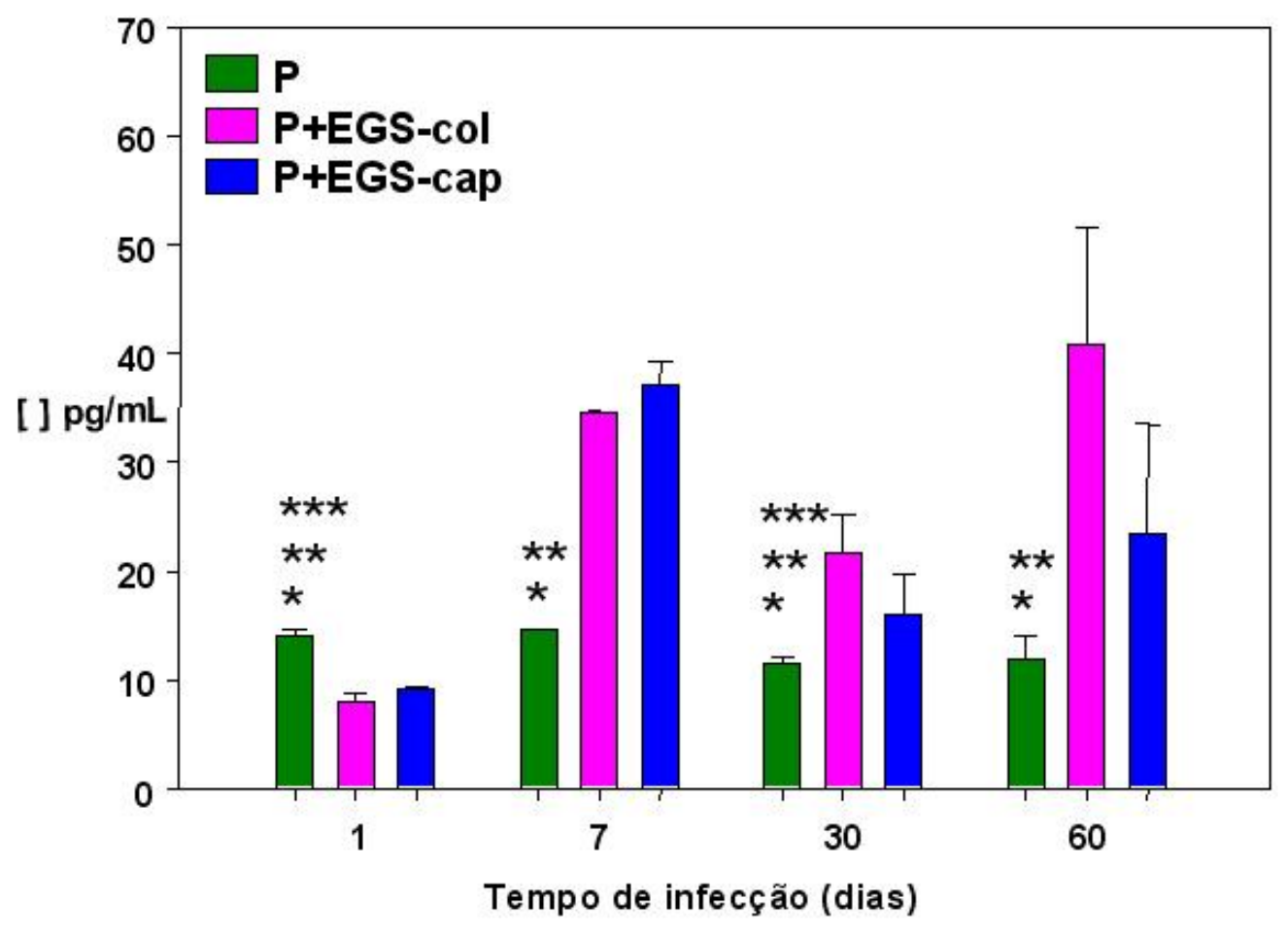

Figura 12 - Determinação da concentração de IL-4 nos sobrenadantes de cultura de células de linfonodos de drenagem de camundongos C57BL/6 infectados com $10^{6}$ formas promastigotas de $L$. (L.) amazonensis na ausência e na presença de extrato de glândula salivar de Lu. longipalpis de colônia ou de captura (P, P+ESG-col e P+EGS-cap). * $p<0.05$ entre os grupos $P$ e $P+E G S-c o l,{ }^{* *} p<0.05$ entre os grupos $P$ e $P+E G S-c a p,{ }^{* * *} p<0.05$ entre os grupos P+EGS-col e P+EGS-cap 


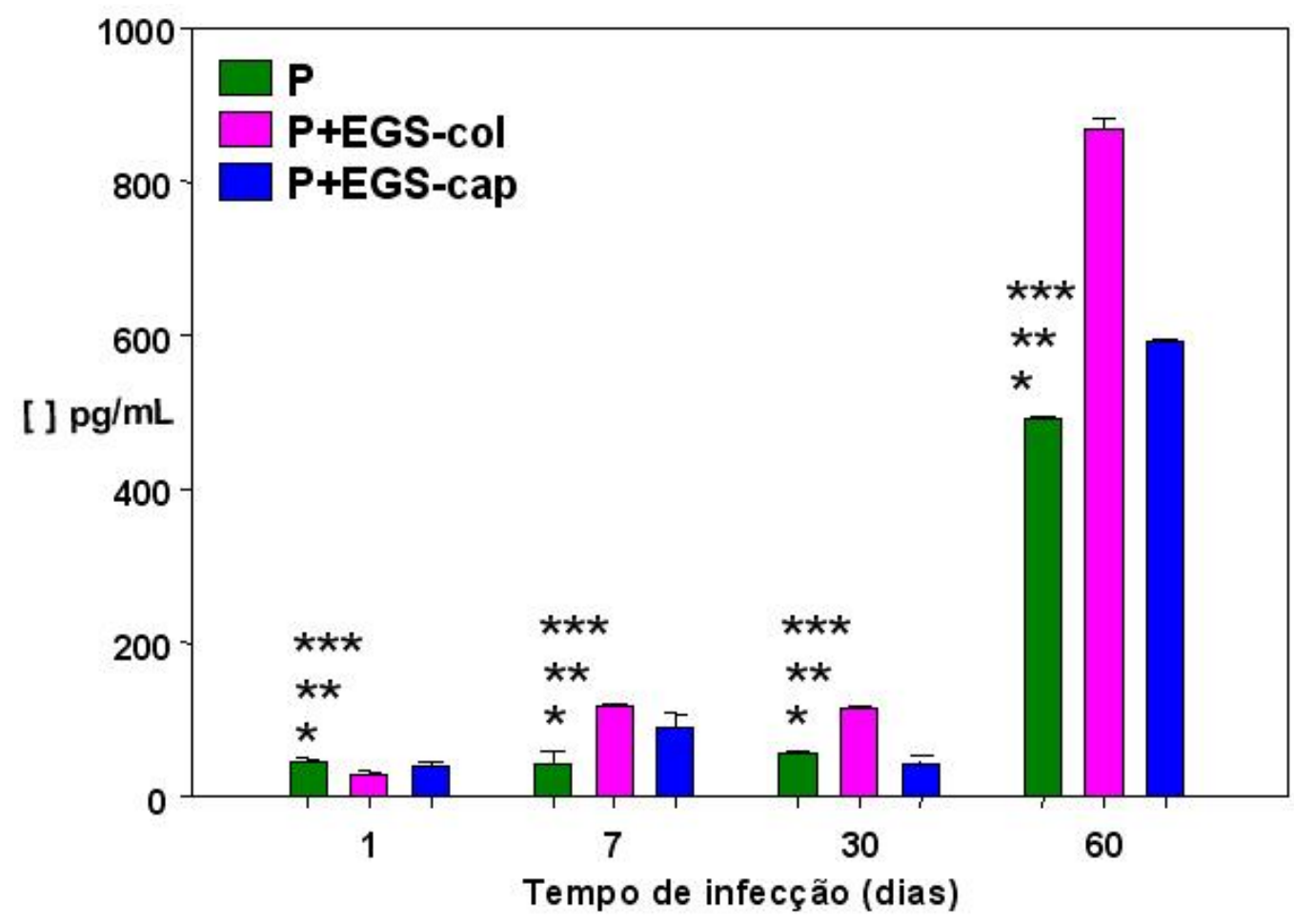

Figura 13 Determinação da concentração de IL-10 nos sobrenadantes de cultura de células de linfonodos de drenagem de camundongos C57BL/6 infectados com $10^{6}$ formas promastigotas de $L$. (L.) amazonensis na ausência e na presença de extrato de glândula salivar de Lu. longipalpis de colônia ou de captura (P, P+ESG-col e P+EGS-cap). * $p<0.05$ entre os grupos $P$ e $P+E G S-c o l,{ }^{* *} p<0.05$ entre os grupos $P$ e $P+E G S-c a p,{ }^{* *} p<0.05$ entre os grupos $\mathrm{P}+\mathrm{EGS}-$ col e $\mathrm{P}+\mathrm{EGS}$-cap

Sumarizando, no primeiro dia de infecção, observou-se baixos níveis de citocinas tanto para resposta Th1 quanto para resposta Th2 em ambos os grupos inoculados com o parasito associado aos extratos de glândulas salivares quando comparado aos animais infectados somente com parasito; já no sétimo dia de infecção, obteve-se níveis mais elevados de citocinas Th2 em ambos os grupos inoculados com parasito e os extratos das diferentes glândulas salivares, enquanto que o grupo infectado somente com o parasito apresentou uma maior expressão de IL-12. Com o estabelecimento da infecção, no trigésimo e sexagésimo dia, os animais inoculados apenas com 
o parasito mostraram uma resposta Th1 mais proeminente com níveis mais elevados de IL-12, INF- $\gamma$ e IL-2 que os grupos inoculados com parasito e os extratos de glândulas salivares; os animais inoculados com parasito na presença de extrato de glândula salivar mostraram uma resposta Th2 proeminente, com níveis mais elevados de IL-4 e IL-10 quando comparado ao grupo infectado somente com parasito, sendo mais expressiva a resposta do grupo infectado com parasito associado ao extrato de glândula salivar de colônia. 
DISCUSSÃO 


\section{DISCUSSÃO}

A Leishmania (Leishmania) amazonensis é uma das 30 espécies de Leishmania mais bem conhecidas que causa a leishmaniose no homem e ela representa um importante agente de leishmaniose cutânea na América do Sul, a forma disseminada borderline e a forma anérgica difusa com conseqüências severas para o paciente (Silveira et al., 2004).

Com o objetivo de determinar o papel da saliva do vetor na evolução da infecção por Leishmania (L.) amazonensis, camundongos C57BL/6 foram escolhidos como modelo experimental, uma linhagem de camundongo que desenvolve lesões crônicas com carga parasitária persistente, diferentemente quando infectados com L. major e L. braziliensis (Sacks \& Noben-Trauth, 2002; Maioli et al., 2004).

Neste estudo, os animais foram co-inoculados com extrato de glândula salivar (EGS) of Lu. longipalpis. Apesar de não ser o vetor clássico de L. (L.) amazonensis, a co-inoculação de camundongos por esta espécie de parasito e saliva de Lu. longipalpis tem sido utilizado e bem aceito na literatura (Theodos et al., 1991; Norsworthy et al., 2004) uma vez que o estabelecimento de colônias de Lu. flaviscutellata não tem se mostrado fácil.

Em adição, nós avaliamos os efeitos imunomodulatórios na leishmaniose cutânea de saliva de vetor capturado em campo, uma abordagem racional para verificar um cenário real de indivíduos que vivem em área endêmica e constantemente expostos a picadas de inseto de campo. De fato, todos os relatos que dizem respeito aos efeitos de exacerbação ou proteção contra a infecção por Leishmania têm sido 
desenvolvidos com saliva de insetos colonizados em laboratório, provavelmente devido à dificuldade de se trabalhar com inseto capturado no campo.

Este estudo mostrou que EGS de Lu. longipalpis capturado no campo aumenta as lesões causadas pela inoculação de L. (L.) amazonensis em camundongos C57BL/6, porém em menor extensão quando comparado com EGS de vetor colonizado em laboratório e com pequena diferença quando os animais foram inoculados somente com o parasito.

O recrutamento de células inflamatórias e a replicação de parasitos pode ser a causa das diferenças observadas nos tamanhos das lesões dos diferentes grupos experimentais. No grupo P+EGS-col, o número de células inflamatórias recuperadas das lesões foi maior que no grupo P+EGS-cap, seguido pelo grupo controle. Além disso, durante o período de infecção estudado, os animais inoculados somente com o parasito mostraram uma maior porcentagem de neutrófilos no sítio da infecção, células que tem um papel importante na resposta protetora inicial contra Leishmania, como célula efetora envolvida na morte dos parasitos (Laurenti et al., 1996) e influenciando o desenvolvimento de resposta imune celular do tipo Th1 (McFarlane et al., 2008). Por outro lado, os macrófagos foram as células mais abundantes recuperadas dos sítios inflamatórios nos animais co-inoculados com EGS, em particular naqueles co-inoculados com EGS de vetor colonizados, tanto na fase aguda como na fase crônica da infecção, provavelmente como conseqüência do recrutamento de macrófagos desencadeado pela saliva de Lu. longipalpis (Teixeira et al., 2005). O tamanho da lesão pode ser também influenciado pela presença da saliva do 
vetor que sabidamente inibe a produção de moléculas com potencial leishmanicida como, óxido nítrico e peróxido de hidrogênio pelos macrófagos assim como sua capacidade de apresentação de antígenos (Theodos et al., 1991; Brodie et al., 2007), importantes eventos para o estabelecimento da Leishmania, favorecendo o crescimento de parasitos dentro das células hospedeiras. Estudos prévios mostraram um maior parasitismo tecidual em camundongos infectados na presença de EGS, especialmente naqueles coinoculados com EGS de vetor colonizados em laboratório, que nos controles (Laurenti et al., 2005).

A saliva de Lu. longipalpis também é capaz de suprimir a resposta proliferativa de células T (Titus, 1998 ; Rohousová et al., 2005). Nossos experimentos mostraram uma menor porcentagem de células T CD4+ em animais co-inoculatos com EGS de vetor colonizado em laboratório, seguida de EGS de vetor capturado no campo, a partir do $7^{\text {th }}$ dia de infecção.

A porcentagem de células T CD8+ foi similar entre os diferentes grupos experimentais, exceto ao $7^{\text {th }}$ dia de infecção quando foi discretamente maior no grupo controle. É sabido que as células T CD8 participam no controle da infecção por Leishmania, através de citotoxicidade assim como através da produção de citocinas, especialmente do IFN- $\gamma$, um potente indutor da produção de óxido nítrico (Muller et al., 1991; Herath et al., 2003 ; Ruiz \& Becker, 2007)

Em nossos experimentos, a produção de IFN- $\gamma$ foi expressiva apenas na fase crônica, aos $60^{\text {th }}$ dia de infecção, em todos os grupos experimentais e foi significantemente maior nos animais inoculados apenas com os parasites $(p<0.05)$. Estes resultados são consistentes com estudos prévios, nos quais o 
IFN- $\gamma$ foi detectado somente nos estágios adiantados da infecção (Afonso \& Scott, 1993; Maioli et al., 2004; Norsworthy et al., 2004). Em adição, é sabido que saliva de Lu. longipalpis saliva determina uma marcada inibição da produção de IFN- $\gamma$ (Rohousová et al., 2005) o que provavelmente influenciou os menores níveis observados nos animais co-inoculados com saliva em nossos experimentos $(p<0.05)$.

Em oposição, IL-12 foi a citocina produzida em maiores níveis na fase aguda, decaindo dramaticamente nos estágios tardios da infecção. Os animais controles foram os que produziram os maiores níveis de IL-12 quando comparados a ambos os grupos co-inoculados com saliva $(\mathrm{p}<0.05)$. Entre eles, os co-inoculados com EGS de vetor capturado foi o que determinou nível mais elevado de IL-12 ( $\mathrm{p}<0.05)$. A IL-12 é sintetizada por células apresentadoras de antígenos e direciona a resposta imune celular para o tipo Th1 com produção de IFN- $\gamma$ e está associada com 0 desenvolvimento de resistência (Alexander et al., 1999); contudo, a saliva de Lu. longipalpis suprime a produção de IL-12, como foi observado em nossos experimentos, fomentando uma resposta imune celular do tipo Th2 (Brodie et al., 2007). Digno de nota, é que a detecção de IL-12 na evolução da infecção não se correlacionou com a produção de IFN- $\gamma$. Recentemente, foi visto que a infecção por $L$. amazonensis leva a inibição da resposta à IL-12 durante a infecção, independente do hospedeiro (Jones et al., 2000) contribuindo com a progressão da doença.

O aumento na produção de IL-4 observada em nossos experimentos, não tem sido descrita na infecção por L. (L.) amazonensis (Maioli et al., 2004; Norsworthy et al., 2004), mesmo na linhagem de camundongos BALB/c, 
altamente suscetíveis (Ji et al., 2002). Em nossos experimentos, a coinoculação com EGS de Lu. longipalpis levou a um aumento na produção de IL-4 principalmente ao $7^{\circ}$ de infecção e na fase crônica ao $60^{\circ}$ dia pósinfecção. Contudo, níveis baixos com pico menor de $40 \mathrm{pg} / \mathrm{mL}$ associados com uma produção transitória vista em nossos experimentos reforçam as observações encontradas de que IL-4 não é o principal modulador da exacerbação da lesão na infecção por $L$. (L.) amazonensis na presença ou na ausência de saliva (Ji et al., 2003; Norsworthy et al., 2004)

Por outro lado, IL-10 tem sido implicada na progressão da doença e na persistência de parasitos tanto na doença humana como em animais experimentais (Bourreau et al., 2001; Kane \& Mosser, 2001; Norsworthy et al., 2004). IL-10 tem um papel importante em controlar a produção de IFN- $\gamma$ pelos linfócitos T suprimindo a produção de IL-12 pelos macrófagos e células dendríticas, além de suprimir a função apresentadora de antígeno destas células por diminuir a expressão de moléculas do complexo maior de histocompatibilidade tipo II (Nylén \& Sacks, 2007).

Como descrito por outros autores (Brodie et al., 2007; Norsworthy et al., 2004), nossos experimentos mostraram níveis substanciais de IL-10 durante a infecção por L. (L.) amazonensis. O EGS de Lu. longipalpis promoveu um aumento significativo da produção de IL-10, assim os grupos co-inoculados com saliva produziram níveis mais elevados $(p<0.05)$ quando comparados aos animais controles, inoculados somente com os parasitos. Os animais infectados na presença de EGS de vetor capturado em campo induziram a produção de níveis menores de IL-10 $(\mathrm{p}<0.05)$ quando comparados aos animais infectados na presença de EGS de vetor colonizado em laboratório. 
Em resumo, apesar da produção de IL-12 na fase aguda e de IFN- $\gamma$ na fase crônica da infecção, os camundongos C57BL/6 inoculados com Leishmania (L.) amazonensis não curaram a infecção e desenvolveram lesões crônicas. Estas lesões desenvolvidas quase na ausência de IL-4 indicam que a suscetibilidade a este parasito não é resultado da produção de IL-4, mas parcialmente devido à presença de IL-10 que pode estar bloqueando IL-12 e tornando o macrófago refratário aos efeitos de ativação de IFN- $\gamma$, o qual contribui para a resolução da infecção. A saliva de vetor de colônia aumentou a suscetibilidade suprimindo a resposta imune celular do tipo Th1 (IFN- $\gamma$ e IL-12) e estimulando uma resposta mais do tipo Th2 (IL-4 e IL-10). Já a saliva de Lu. longipalpis capturada em campo levou a produção de citocinas, embora em menores níveis, tanto de Th1 como de Th2.

Como já descrito em relação a outras espécies e também em colônias da mesma espécie (Wahba \& Riera, 2006) é possível que a composição de proteínas da saliva de vetor capturado em campo seja diferente em relação à saliva de vetor colonizado em laboratório, o que pode ser responsável pelo menor efeito visto na exacerbação da lesão. Evidências em relação a isto foram descrita recentemente pelo nosso grupo (Laurenti et al., 2005).

Pelo que tem sido descrito na literatura, todos os estudos em relação ao efeito de exacerbação da saliva do vetor nas lesões causadas pela infecção por Leishmania tem sido desenvolvidos com a utilização de saliva de vetor oriundo de colônias de laboratório. Quando a mesma fonte de saliva foi utilizada em nossos experimentos, resultados semelhantes foram encontrados; porém, um fraco efeito de exacerbação no tamanho da lesão foi 
observado quando EGS de Lu. longipalpis oriundo de captura em campo foi utilizada.

Em conclusão, estes achados mostram que, na natureza, a saliva do vetor pode não ter um papel importante na facilitação da infecção como previamente descrito por outros autores. Como uma exacerbação significante não foi vista sob condições mais naturais de transmissão do parasito (uso de saliva de vetor capturado em campo), o foco em proteínas salivares como candidatas para vacina contra Leishmania pode não ser relevante como estratégia profilática para prevenção da leishmaniose, uma doença que afeta milhões de pessoas por todo o mundo. 


\section{CONCLUSÕES}




\section{CONCLUSÕES}

- Os camundongos C57BL/6, inoculados com formas promastigotas de $L$. (L.) amazonensis na presença dos extratos de glândulas salivares de $L u$. longipalpis oriundos de colônia ou capturados em campo mostram um tamanho de lesão maior, tanto nas patas como nas orelhas, quando comparado a camundongos infectados somente com o parasito; sendo que este aumento foi mais evidente no grupo co-inoculado com o extrato de glândula salivar de colônia.

- Maior número de células inflamatórias foi recuperado dos tecidos dérmicos das orelhas de camundongos C57BL/6 infectados com L. (L.) amazonensis na presença dos extratos de glândulas salivares de $L u$. longipalpis colonizados e capturados em campo quando comparados ao grupo inoculado somente com o parasito, tanto na fase aguda quanto na fase crônica da infecção, sendo maior no grupo infectado na presença do extrato de glândula salivar de colônia.

- A população celular recuperada das lesões desencadeadas pela inoculação por L. (L.) amazonensis na orelha de camundongos C57BL/6 na presença dos extratos de glândulas salivares de Lu. longipalpis mostrou uma maior expressão de macrófagos (células $\mathrm{F} 4 / 80+$ ), e menor de neutrófilos (células Ly6+) e linfócitos (células CD3+, CD4+ e CD8+) quando comparado à população celular recuperada do tecido dérmico das orelhas dos animais 
inoculados somente com o parasito, sendo que este perfil foi mais evidente nos animais co-inoculados com a saliva de vetor oriundo de colônia.

- A análise do perfil de citocinas produzidas pelas células de linfonodos de drenagem de camundongos C57BL/6 infectados com L. (L.) amazonensis na ausência e na presença dos extratos de glândulas salivares de Lu. longipalpis oriundos de colônia ou de capturado em campo mostrou no grupo coinoculado com o parasito e as salivas uma falha na resposta imune celular do tipo Th1, com produção de níveis mais baixos de IL-12, IFN- $\gamma$ e IL-2 quando comparado ao grupo inoculado somente com o parasito. Em contrapartida, a resposta imune celular do tipo Th2, avaliada pela produção de IL-4 e IL-10, foi mais proeminente nestes grupos, sendo que o grupo co-inoculado com o extrato de glândula salivar de colônia este perfil foi mais evidente.

- O estudo mostrou diferenças importantes no efeito biológico de ambos os extratos de glândulas salivares utilizados. Enquanto a saliva de vetor de colônia confirmou os efeitos de exacerbação da infecção, a saliva de vetor de captura mostrou um efeito de exacerbação mais discreto com um comportamento intermediário entre o grupo co-inoculado com saliva de colônia e o grupo controle, animais inoculados somente com o parasito 


\section{REFERÊNCIAS}




\section{REFERÊNCIAS}

Afonso LC, Scott P. Immune responses associated with susceptibility of C57BL/10 mice to Leishmania amazonensis. Infect Immun. 1993; 61 (7): 2952-9

Alexander J, Satoskar AR, Russel DG. Leishmania species: model of intracellular parasitism. J Cell Sci. 1999; 112 (18): 2993-3002.

Almeida MA, Jesus EE, Sousa-Atta ML, Alves LC, Berne ME, Atta AM. Clinical and serological aspects of visceral leishmaniasis in Northeast Brazilian dogs naturally infected with Leishmania chagasi. Vet Parasitol. 2005; $127(3-4): 227-32$.

Almeida MC, Vilhena V, Barral A. Barral-Netto M.. Leishmanial infection: analysis of its first steps. A Review. Mem Inst Oswaldo Cruz (Rio de Janeiro). 2003; 98 (7): 861-870.

Andrade BB, Oliveira Cl, Brodskyn Cl, Barral A, Barral-Netto M. Role of sand fly saliva in human and experimental leishmaniasis: current insights. Scand $J$ Immunol. 2007; 66 (2-3): 122-7.

Awasthi A, Mathur RK, Saha B, Immune response to Leishmania infection. Indian J Med Res. 2004; 119 (6): 238-58. 
Barral A, Honda E, Caldas A, Costa J, Vinhas V, Rowton ED, Valenzuela JG, Charlab R, Barral-Netto M, Ribeiro JMC. Human immune response to sand fly salivary gland antigens: a useful epidemiological marker? Am J Trop Med Hyg. 2000; 62 (6): 740-45.

Basano SA, Camargo LMA. Leishmaniose tegumentar americana: histórico, epidemiologia e perspectivas de controle. Rev Bras de Epidemiol. 2004; 7 (3): 328-37.

Belkaid Y, Mendez S, Lira R, Kadambi N, Milon G, Sacks D. A Natural model of Leishmania major infection reveals a prolonged "silent" phase of parasite amplification in the skin before the onset of lesion formation and immunity. $J$ Immunol. 2000; 165 (2): 969-77.

Bittencourt AL, Barral A. Evaluation of the histophatological classifications of American cutaneous and mucocutaneous leishmaniasis. Mem Inst Oswaldo Cruz (Rio de Janeiro). 1991; 86 (1): 51-6.

Bogdan C. Mechanisms and consequences of persistence of intracellular pathogens: leishmaniasis as an example. Cell Microbiol. 2008; 10 (6): 122134.

Brasil, Ministério da Saúde. Secretaria de Vigilância em Saúde. Departamento de Vigilância Epidemiológica. Manual de Vigilância da Leishmaniose Tegumentar Americana / Ministério da Saúde, Secretaria de 
Vigilância em Saúde, Departamento de Vigilância Epidemiológica. - 2 ed. Brasília: Editora do Ministério da Saúde, 2007. 182 p. - (Série A. Normas e Manuais Técnicos).

Brodie TM, Smith MC, MV, Titus RG. Immunomodulatory effects of the Lutzomyia longipalpis salivary gland protein maxadilan on mouse macrophages. Infect Immun. 2007; 75 (5): 2359-65.

Bourreau E, Prevot G, Gardon J, Pradinaud R. Launois P. High intralesional interleukin-10 messenger RNA expression in localized cutaneous leishmaniasis is associated with unresponsiveness to treatment. J Infect Dis. 2001; 184: 1628-1630.

Bruchhaus I, Roeder T, Rennenberg A, Heussler VT. Protozoan parasites: programmed cell death as a mechanism of parasitism. Trends Parasitol. 2007; 23 (8): 376-83.

Campanelli AP, Roselino AM, Cavassani KA, Pereira MSF, Mortara RA, Brodskyn Cl, Gonçalves HS, Belkaid Y, Barral-Netto M, Barral A, Silva JS. CD4+ CD25+T cells in Skin Lesions of Patients with Cutaneous Leishmaniasis Exhibit Phenotypic and Functional Characteristics of Natural Regulatory T Cells. J Infect Dis. 2006; 193 (9): 1313-22.

Carvalho LP, Passos S, Bacellar O, Lessa M, Almeida RP, Magalhães A, Dutra WO, Gollob KJ, Machado P, Jesus AR. Differential immune regulation 
of activated $\mathrm{T}$ cells between cutaneous and mucosal leishmaniasis as a model for pathogenesis. Parasite Immunol. 2007; 29 (5): 251-8.

Cavalcante RR, Pereira MH, Gontijo NF. Anti-complement activity in the saliva of phlebotomine sand flies and other haematophagous insects. Parasitology. 2003; 127 (1): 87-93.

Chakraborty P, Ghosh D, Basu MK. Modulation of macrophage mannose receptor affects the uptake of virulent and avirulent Leishmania donovani promastigotes. J Parasitol. 2001; 87 (5): 1023-7.

Cunningham AC. Parasitc adaptive mechanisms in Infection by Leishmania. Exp Mol Pathol. 2002; 72 (2): 132-41.

Cruz A M, Pirmet C. Leishmaniose Tegumentar Americana. In: Coura, J.R. Dinâmica das Doenças Infecciosas e Parasitárias. 2v. Rio de Janeiro: Guanabara-Koogan; 2005. p.697-712.

Giunchetti R C, Corrêa-Oliveira R, Martins-Filho O A, Teixeira-Carvalho A, Roatt B M, de Oliveira Aguiar-Soares R D, Coura-Vital W, de Abreu R T, Malaquias L C, Gontijo N F, Brodskyn C, de Oliveira C I, Costa D J, de Lana M, Reis A B. A killed Leishmania vaccine with sand fly saliva extract and saponin adjuvant displays immunogenicity in dogs. Vaccine. 2008; 26 (5): 623-38. 
Gomes R B, Mendonça I L, Silva V C, Ruas J, Silva M B, Cruz M S, Barral A,

Costa C H. Antibodies against Lutzomyia longipalpis saliva in the fox Cerdocyon thous and the sylvatic cycle of Leishmania chagasi. Trans R Soc Trop Med Hyg. 2007; 101 (2): 127-33.

Hall LR, Titus RG. Sandy fly vector saliva selectively modulates macrophage functions that inhibit killing of Leishmania major and nitric oxide production. $J$ Immunol. 1995; 155 (7): 3501-6.

Herath S, Kropf P \& Müller I. Cross-talk between CD8 and CD4 T cells in experimental cutaneous leishmaniasis: $\mathrm{CD} 8^{+} \mathrm{T}$ cells are required for optimal IFN- $\gamma$ production by $\mathrm{CD}^{+}{ }^{+} \mathrm{T}$ cells. Parasite Immunol. 2003; 25: 559-567.

Hölscher C, Arendse B, Schwegmann A, Myburgh E, Brombacher F. Impairment of alternative macrophage activation delays cutaneous Leishmaniasis in nonhealing BALB/c mice. J Immunol. 2006; 176 (2): 111521.

Ilg T. Lipophosphoglycan is not required for infection of macrophages or mice by Leishmania mexicana. EMBO J. 2001; 9 (9): 1953-62.

Ji J, Sun J, Soong L. Impaired expression of inflammatory cytokines and chemokines at early stages of infection with Leishmania amazonensis. Infec Immun. 2003; 71 (8): 4278-88. 
Jones D E, Buxbaum L U, Scott P. IL-4-independent inhibition of IL-12 responsiveness during Leishmania amazonensis infection. J Immunol. 2000 165 (1): 364-72.

Joshi PB, Kelly BL, Kamhawi S, Sacks DL, McMaster WR. Targeted gene deletion in Leishmania major identifies leishmanolysin (GP63) as a virulence factor. Mol Biochem Parasitol. 2002; 120 (1): 33-40.

Kamhawi S. Phlebotomine sand flies and Leishmania parasites: friends or foes? Trends Parasitol. 2006; 22 (9): 439-45.

Kamhawi S. The biological and immunomodulatory properties of sand fly saliva and its role in the establishment of Leishmania infections. Microbes Infec. 2000; 2 (14): 1765-73.

Kane MM, Mosser DM. The role of IL-10 in promoting disease progression in leishmaniasis. J Immunol. 2001; 166 (2): 1141-7.

Lainson R, Shaw J.J. Evolution, classification and geographic distribution. In: Peters, W. Killick-Kendric, R. (Ed.) The leishmaniasis in biology and medicine. London: Academic Press, 1987, v.1, p.1-20.

Lainson R, Rangel EF. Lutzomyia longipalpis and the eco-epidemiology of American visceral leishmaniasis, with particular reference to Brazil - A review. Mem Inst Oswaldo Cruz (Rio de Janeiro). 2005; 100 (8): 811-27. 
Laurenti M D, Corbett C E P, Sotto M N, Sinhorini I L, Goto H. The role of complement in the acute inflammatory process in the skin and in host-parasite interation in hamsters inoculated with Leishmania (Leishmania) chagasi Int $\mathrm{J}$ Exp Pathol. 1996; 77 (1): 15-24.

Laurenti M D, Matta V L R, Rocha M C, Secundino N F C, Corbett C E P, Pimenta P F P. 2Characterization of the acute inflammatory response in the ear dermis of mice infected with L. (L.) amazonensis and Lu. Longipalpis saliva. Arq Inst Pasteur Tunis. 2005; 82 (1): 149-50.

Lang $\mathrm{T}$, Courret N, Colle JH, Milon G, Antoine JC. The levels and patterns of cytokines produced by CD4 T lymphocytes of BALB/C mice infected with Leishmania major by inoculation into the ear dermis depend on the Infectiousness and size of the Inoculum. Infec Immun 2003; 71 (5): 2674-83.

Leopoldo PT, Machado PR, Almeida RP, Schriefer A, Giudice A, de Jesus AR, Ho, JL, Guimarães LH, Bacellar O, Carvalho EM. Differential effects of antigens from $L$. braziliensis isolates from disseminated and cutaneous leishmaniasis on in vitro cytokine production. BMC Infec Dis. 2005; 25 (6): 75.

Lima HC, Titus RG. Effects of sand fly vector saliva on development of cutaneous lesions and the immune response to Leishmania braziliensis in BALB/c mice. Infec Immun. 1996; 64 (12): 5442-5. 
Leiby, D.A., Kanesa-thasan, N., Scott, P., Nacy, C.A. 1994 Leishmaniasis. Parasitic Infection and the Immune System. p. 87-118.

Lipoldová M, Svobodová M, Krulová M, Havelková H, Badalová J, Nohynková E, Holán V, Hart AA, Volf P, Demant P. Susceptibility to Leishmania major infection in mice: multiple loci and heterogeneity of immunopathological phenotypes. Genes Immun. 2000; 1 (8): 200-6.

Lipoldová M, Svobodová M, Havelková H, Krulová M, Badalová J, Nohynková E, Hart AA, Schlegel D, Volf P, Dement P. Mouse genetic model for clinical and immunological heterogeneity of leishmaniasis. Immunogenetics. 2002; 54 (3): 174-83.

Maioli T U, Takane E, Arantes R M, Fietto J L, Afonso L C. Immune response induced by New World Leishmania species in C57BL/6 mice. Parasitol Res. 2004; 94 (3): 207-12.

McFarlane E, Perez C, Charmoy M, Allenbach C, Carter KC, Alexander J, Tacchini-Cottier F. Neutrophils contribute to development of a protective immune response during onset of infection with Leishmania donovani. Infect Immun. 2008; 76 (2): 532-41.

Mbow ML, Bleyenberg JA, Hall LR, Titus RG. Phlebotomus papatasi sand fly gland lysate down-regulates a Th1, but up-regulates a Th2, response in mice infected with Leishmania major. J Immunol. 1998; 161 (10): 5571-7. 
Moll H, Scharner A, Kämpgen E. Increased interleukin 4 (IL-4) receptor expression and IL-4-induced decrease in IL-12 production by Langerhans cells infected with Leishmania major. Infect Immun. 2002; 70 (3): 1627-30.

Monteiro MC, Lima HC, Souza AA, Titus RG, Romão PR, Cunha FQ. Effect of Lutzomyia longipalpis salivary gland extracts on leukocyte migration induced by Leishmania major. Am J Trop Med Hyg. 2007; 76 (1): 88-94.

Moro O, Lerner EA. Maxadilan, the vasodilator from sand flies, is a specific pituitary adenylate cyclase activating peptide type I receptor agonist. J Biol Chem. 1997; 272 (2): 966-70.

Morris RV, Shoemaker CB, David JR, Lanzaro GC, Titus RG. Sandfly maxadilan exacerbates infection with Leishmania major and vaccinating against it protects against $L$. major infection. J Immunol. 2001; 167 (9): 522630.

Mosser D M, Burke S K, Contavas E E, Wedgwood JF, Edelson P J. Leishmania species: mechanisms of the complement activation by five strains of promastigotes. Exp Parasitol. 1986; 62 (3): 394-404.

Mosser DM, Edelson PJ. The third component of complement (C3) is responsible for the intracellular survival of Leishmania major. Nature. 1987; 327 (6120): 329-31. 
Moura TR, Novais FO, Oliveira F, Clarêncio J, Noronha A, Barral A, Brodskyn C, Oliveira $\mathrm{Cl}$. Toward a novel experimental model of infection to study American cutaneous leishmaniasis caused by Leishmania braziliensis Infec Immun. 2005; 73 (9): 5827-34.

Müller I, Pedrazzini T, Kropf P, Louis J, Milon G. Establishment of resistance to Leishmania major infection in susceptible BALB/c mice requires parasitespecific CD8+ T cells. Int Immunol. 1991; 3 (6): 587-97.

Mukbel RM, Patten C Jr, Gibson K, Ghosh M, Petersen C, Jones DE. Macrophage killing of Leishmania amazonensis amastigotes requires both nitric oxide and superoxide. Am J Trop Med Hyg. 2007; 76 (4): 669-75.

Murray HW, Berman JD, Davies CR, Saraiva NG. Advances in leishmanisis. Lancet. 2005; 366 (9496): 1561-77.

Nylén S, Sacks D. Interleukin-10 and the pathogenesis of human visceral leishmaniasis. Trends Immunol. 2007; 28 (9): 378-84.

Norsworthy NB, Sun J, Elnaiem D, Lanzaro G, Soong L. Sand fly saliva enhances Leishmania amazonensis infection by modulating interleukin-10 production. Infect Immun. 2004; 72 (3): 1240-7 
Oliver M, Gregory DJ, Forget G. Subversion mechanisms by which Leishmania parasites can escape the host immune response: a signaling point of view. Clin Microbiol Rev. 2005; 18 (2): 293-305.

Ponte-Sucre A, Heise D, Moll H. Leishmania major lipophosphoglycan modulates the phenotype and inhibits migration of murine Langerhans cells. Immunology. 2001; 104 (4): 462-7.

Pinheiro RO, Rossi-Bergmann B. Interferon-gamma is required for the late but not early control of Leishmania amazonensis infection in C57BI/6 mice. Mem. Inst. Oswaldo Cruz (Rio de Janeiro). 2007; 102 (1): 79-82.

Rittig MG, Bogdan C. Leishmania- host-cell interaction: complexities and alternative views. Parasitol Today. 2000; 16 (7): 292-7.

Roberts MT. Current understandings on the immunology of leishmaniasis and recent developments in prevention and treatment. Br Med Bull. 2006; 75-76: 115-30.

Rogers ME, Bates PA. Leishmania manipulation of sand fly feeding behavior results in enhanced transmission. PLoS Pathog. 2007; 3 (6): e91.

Rogers ME, Ilg T, Nikolaev AV, Ferguson MA, Bates PA. Transmission of cutaneous leishmaniasis by sand flies is enhanced by regurgitation of fPPG. Nature 2004; 430 (6998): 463-7. 
Rohousová I, Volf P, Lipoldova M. Modulation of murine cellular immune response and cytokine production by salivary gland lysate of three sand fly species. Parasite Immunol. 2005; 27 (12): 469-73.

Ruiz JH, Becker I. CD8 cytotoxic T cells in cutaneous leishmaniasis. A Review. Parasite Immunol. 2007; 29 (12): 671-8.

Sacks D, Kamhawi S, Molecular aspects of parasite-vector and vector-host interactions in leishmaniasis. Annu Rev Microbiol. 2001; 55: 453-83.

Sacks, D, and N. Noben-Trauth. The immunology of susceptibility and resistance to Leishmania major in mice. Nat Rev Immunol. 2002; 2: 845-858.

Shaw J J, Lainson R, Ryan L, Braga R R, McMahon-Pratt D, David J R. Leishmaniasis in Brazil: XXIII the identification of Leishmania braziliensis in wild-caught neotropical sandflies using monoclonal antibodies. Trans R Soc Trop Med Hyg. 1987; 81 (1): 69-72.

Vannier-Santos MA, Martiny A, de Souza W. Cell biology of Leishmania spp: invading and evading. Curr Pharm Des. 2002; 8 (4): 297-318.

Schoeler GB,Wikel SK. Modulation of host immunity by haematophagous arthropods. Ann Trop Med Parasitol. 2001; 95 (8): 755-71. 
Silveira FT, Lainson R, Corbett CE. Further observations on clinical, histopathological, and immunological features of borderline disseminated cutaneous leishmaniasis caused by Leishmania (Leishmania) amazonensis. Mem Inst Oswaldo Cruz (Rio de Janeiro). 2005; 100 (5): 524-34.

Silveira FT, Lainson R, Corbett CE. Clinical and immunopathological spectrum of American cutaneous leishmaniasis with special reference to the disease in Amazonian Brazil: A review. Mem Inst Oswaldo Cruz (Rio de Janeiro). 2004; 99 (3): 239-51.

Silveira VMS. Evolução da infecção experimental causada pela Leishmania (Leishmania) amazonensis em camundongos C57BL/6 na presença do lisado de glândula salivar de Lutzomyia longipalpis. [dissertação]. São Paulo: Faculdade de Medicina Veterinária e Zootecnia, Universidade de São Paulo; 2003

Soares PP, Turco SJ. Lutzomyia longipalpis (Díptera: Psychodidae: Phlebotominae): A Review. Anais da Academia Brasileira de Ciências. 2003; 75 (3): 301-30.

Solbach W, Laskay T. The host response to Leishmania infection. Adv Immunol. 2000; 74: 275-317.

Sousa FC, Silva MP, Sherlok I, Paixão MS, Carvalho LCPC, Santos WLC. Dissociation between vasodilatation and Leishmania infection-enhancing 
effects of sand fly saliva and maxadilan. Mem do Inst Oswaldo Cruz (Rio de Janeiro) 2001; 96 (7): 997-9.

Späth GF, Epstein L, Leader B, Singer SM, Avila HA, Turco SJ, Beverley SM. Lipophosphoglycan is a virulence factor distinct from related glycoconjugates in the protozoan parasite Leishmania major. Proc Nat Acad Sci U S A. 2000; 97 (16): 9258-63.

Späth GF, Lye LF, Segawa H, Sacks DL, Turco SJ, Beverley SM. Persistence without pathology in phosphoglycan-deficient Leishmania major. Science 2003; 301 (5637): 1241-3.

Teixeira CR, Teixeira MJ, Gomes RB, Santos CS, Andrade BB, RaffaeleNetto,I, Silva JS, Guglielmotti A, Miranda JC, Barral A, Brodskyn C, Netto MB. Saliva from Lutzomyia longipalpis induces CC chemokine ligand 2/monocyte chemo attractant protein-1 expression and macrophage recruitment. $\mathrm{J}$ Immunol. 2005; 175 (12): 8346-53.

Theodos C M, Ribeiro J M, Titus R G. Analysis of enhancing effect of sand fly saliva on Leishmania infection in mice. Infect Immun. 1991; 59 (5): 1592-8.

Thiakaki M, Rohousova I, Volfova V, Volf P, Chang KP, Soteriadou K. Sand fly specificity of saliva-mediated protective immunity in Leishmania amazonensis-BALB/c mouse model. Microbes Infect. 2005; 7 (4): 760-6. 
Titus RG. Salivary gland lysate from the sand fly Lutzomyia longipalpis suppresses the immune response of mice to sheep red blood cells in vivo and concanavalin A in vitro. Exp Parasitol. 1998; 89 (1): 133-6.

Titus RG, Ribeiro JM. Salivary gland lysates from the sandfly Lutzomyia longipalpis enhance Leishmania infectivity. Science. 1988; 239 (4845): 13068.

Tuon FF, Amato VS, Bacha HA, AlMusawi T, Duarte MI, Neto VA. Toll-Like receptors and leishmaniasis. Infec Immun. 2008; 76 (3): 866-72.

Valenzuela JG. High-throughput approaches to study salivary proteins and genes from vectors of disease. Insect Biochem Mol Biol. 2002; 32 (10): 1199209.

Volf $\mathrm{P}$, Tesarová $\mathrm{P}$, Nohýnkova E N. Salivary proteins and glycoproteins in phlebotomine sandflies of various species, sex and age. Med Vet Entomol. 2000; 14 (3): 251-6.

Wahba M, Riera C. Salivary gland composition of some Old World vector sand fly. J Egypt Soc Parasitol. 2006; 36 (1): 289-96.

Wanderley JL, Moreira ME, Benjamin A, Bonomo AC, Barcinski MA. Mimicry of apoptotic cells by exposing phosphatidylserine partipates in the 
establishment of amastigotes of Leishmania (L.) amazonensis in mammalian hosts. J Immunol. 2006; 176 (3): 1834-9.

Warburg A. The structure of female sand fly (Phlebotomus papatasi) alimentary canal. Trans R Soc Trop Med Hyg. 2008; 102 (2): 161-6. 